\title{
Sensitivity of stomatal conductance to soil moisture: implications for tropospheric ozone
}

\author{
Alessandro Anav ${ }^{1}$, Chiara Proietti ${ }^{1}$, Laurent Menut ${ }^{2}$, Stefano Carnicelli ${ }^{3}$, Alessandra De Marco ${ }^{4}$, and Elena Paoletti ${ }^{1}$ \\ ${ }^{1}$ Institute of Sustainable Plant Protection, National Research Council , Sesto Fiorentino, Italy \\ ${ }^{2}$ Laboratoire de Meteorologie Dynamique, LMD/IPSL, École Polytechnique, Palaiseau, France \\ ${ }^{3}$ Earth Sciences Department, University of Florence, Florence, Italy \\ ${ }^{4}$ Italian National Agency for New Technologies, Energy and the Environment (ENEA), \\ C.R. Casaccia, S. Maria di Galeria, Italy
}

Correspondence: Alessandro Anav (alessandro.anav@ipsp.cnr.it)

Received: 13 November 2017 - Discussion started: 30 November 2017

Revised: 28 March 2018 - Accepted: 4 April 2018 - Published: 25 April 2018

\begin{abstract}
Soil moisture and water stress play a pivotal role in regulating stomatal behaviour of plants; however, in the last decade, the role of water availability has often been neglected in atmospheric chemistry modelling studies as well as in integrated risk assessments, despite the fact that plants remove a large amount of atmospheric compounds from the lower troposphere through stomata.

The main aim of this study is to evaluate, within the chemistry transport model CHIMERE, the effect of soil water limitation on stomatal conductance and assess the resulting changes in atmospheric chemistry testing various hypotheses of water uptake by plants in the rooting zone.

Results highlight how dry deposition significantly declines when soil moisture is used to regulate the stomatal opening, mainly in the semi-arid environments: in particular, over Europe the amount of ozone removed by dry deposition in one year without considering any soil water limitation to stomatal conductance is about $8.5 \mathrm{TgO}_{3}$, while using a dynamic layer that ensures that plants maximize the water uptake from soil, we found a reduction of about $10 \%$ in the amount of ozone removed by dry deposition $\left(\sim 7.7 \mathrm{TgO}_{3}\right)$. Although dry deposition occurs from the top of canopy to ground level, it affects the concentration of gases remaining in the lower atmosphere, with a significant impact on ozone concentration (up to $4 \mathrm{ppb}$ ) extending from the surface to the upper troposphere (up to $650 \mathrm{hPa}$ ).
\end{abstract}

Our results shed light on the importance of improving the parameterizations of processes occurring at plant level (i.e. from the soil to the canopy) as they have significant implica- tions for concentration of gases in the lower troposphere and resulting risk assessments for vegetation or human health.

\section{Introduction}

Plant-level water cycling and exchange of air pollutants between atmosphere and vegetation are intimately coupled (Eamus, 2003; Domec et al., 2010); thus, any factor affecting root water absorption by plants is expected to impact the concentration of gases in the lower troposphere by changing deposition rates. In fact, atmospheric gases, including air pollutants, are primarily removed from the troposphere by dry deposition to the Earth's surface (Hardacre et al., 2015; Monks et al., 2015). A major part of dry deposition to vegetation is regulated by stomata opening, which strongly depends on the amount of water available in the soil (Büker et al., 2012). Therefore a proper quantification of soil water content as well as a proper understanding of stomatal response to soil moisture is required for correctly quantifying the concentration of gases in the atmosphere, particularly in waterlimited ecosystems (dry and semidry environments), which cover $41 \%$ of Earth's land surface (Reynolds et al., 2007).

Among common air gasses, ozone $\left(\mathrm{O}_{3}\right)$ plays a pivotal role in the Earth system: it affects climate with a direct radiative forcing of $0.2-0.6 \mathrm{~W} \mathrm{~m}^{-2}$ (Shindell et al., 2009, 2013; Ainsworth et al., 2012; Myhre et al., 2013) and the ecosystems, causing a reduction in carbon assimilation by vegetation (Wittig et al., 2009) that accelerates the rate of rise 
in $\mathrm{CO}_{2}$ concentrations with indirect implications for climate change (Sitch et al., 2007). In addition, $\mathrm{O}_{3}$ accelerates leaf senescence (Gielen et al., 2007), changes plants' susceptibility to abiotic and biotic stress factors (Karnosky et al., 2002) and causes the response of stomata to environmental stimuli to be sluggish or impaired (Hoshika et al., 2015).

At the European level, the model currently parameterized for European vegetation and developed to estimate surface $\mathrm{O}_{3}$ fluxes is the $\mathrm{DO}_{3} \mathrm{SE}$ (Deposition of $\mathrm{O}_{3}$ and Stomatal Exchange) model (Emberson et al., 2000); it is widely used embedded within chemistry transport models (CTMs) (Tuovinen et al., 2004; Simpson et al., 2007, 2012; Menut et al., 2014) to estimate dry deposition rates as well as stand-alone for $\mathrm{O}_{3}$ risk assessment (Emberson et al., 2007; Tuovinen et al., 2009; Klingberg et al., 2014; Anav et al., 2016; Sicard et al., 2016; Karlsson et al., 2017). The $\mathrm{DO}_{3}$ SE model is based on the multiplicative Jarvis algorithm for calculation of stomatal conductance (Jarvis, 1976), which integrates the effects of multiple climatic factors, vegetation characteristics and local features (Emberson et al., 2000). The leaf-level stomatal conductance is estimated considering the variation in the maximum stomatal conductance $\left(g_{\max }\right)$ with photosynthetic photon flux density, surface air temperature, and vapour pressure deficit. However, this original formulation of the $\mathrm{DO}_{3} \mathrm{SE}$ model presented a main limitation (Simpson et al., 2007; Tuovinen et al., 2009; Mills et al., 2011): for both forests and crops the model did not take into account the limitation due to soil water content. This approach ensured that stomatal fluxes were maximized, corresponding to conditions expected for irrigated areas (Simpson et al., 2007), but, in semi-arid environments, like the Mediterranean Basin, the amount of atmospheric gases entering the leaves might be compromised by the exclusion of the influence of drought on stomatal conductance (Tuovinen et al., 2009; Mills et al., 2011; Büker et al., 2012; Anav et al., 2016; De Marco et al., 2016). Following this assumption, the role of soil moisture on stomatal $\mathrm{O}_{3}$ fluxes has been often neglected in risk assessment studies because soil water is very difficult to model accurately in large-scale models, as it depends on parameters (such as soil texture, vegetation characteristics and rooting depth) that are not easily available in the frame of large-scale models (Simpson et al., 2007, 2012; Büker et al., 2012).

However, in the last decade the importance of soil water stress on vegetation has been well demonstrated in several studies reporting a large reduction in the amount of air gases taken up from the atmosphere during heat waves or drought years (e.g. Ciais et al., 2005; Granier et al., 2007; Reichstein et al., 2007) with species responding in different ways to scarce water availability, depending on eco-hydrological properties (Granier et al., 1996; Pataki et al., 2000; Pataki and Oren, 2003) and drought avoidance and tolerance strategies (Martinez-Ferri et al., 2000; Bolte et al., 2007). For instance, drought-avoiding species (e.g. Pinus spp.) prevent damage by an early stomatal closure that leads to a sharp carbon assimilation inhibition, whereas drought-tolerant species (e.g.
Quercus spp.) exhibit a simultaneous decrease in stomatal conductance and water potential (Guehl et al., 1991; Picon et al., 1996) that does not significantly limit carbon assimilation. Nevertheless, both strategies have severe implications for the concentration of gases in the lower troposphere.

Moreover, it is important to take into account that soil drying does not occur at the same rate at different depths, and the drying rate is more pronounced in the superficial soil layers than in the deeper ones. Overall, deep-rooted forest systems take up water from deep to shallow soil horizons (Aranda et al., 2012). In contrast, shallow-rooted grass normally adsorbs available soil water from top-middle soil, while shrubs can take up soil water adaptively from top to deep soil layers, with increased use of topsoil water under non-drought stress and a tendency of using water from deeper soil under drought stress (Wu et al., 2017). Thus, plants able to develop a deeper root system are usually more tolerant to low water availability than plants with a more superficial root system (Canadell et al., 1996). Jackson et al. (2000) showed that differences in rooting depth patterns vary between world's major plant biomes, with plants of xeric environments having deeper root-depth distributions than plants in more humid environments. In contrast, Schenk and Jackson (2002) found that maximum rooting depths tend to be shallowest in arid regions and deepest in sub-humid regions.

Consequently, the role of root systems is fundamental in stomatal conductance regulation and thus in atmospheric chemistry modelling: results from a sensitivity analysis of ozone dry deposition model indicate that soil moisture is one of the most crucial factors of deposition in the continental climate region (Mészáros et al., 2009). For these reasons, recently the $\mathrm{DO}_{3} \mathrm{SE}$ model has been improved to account for the soil moisture limitation to stomatal conductance (Büker et al., 2012).

Chemistry transport models are widely used to estimate the concentration of gases in atmosphere at both regional and global scale; in these models the concentration of a given gas species is mainly regulated and parameterized by three different processes: atmospheric transport, chemical production/destruction and losses to surface by dry deposition (Monks et al., 2015). Within these models, the dry deposition is generally simulated through an electrical resistance analogy (Wesely, 1989; Monks et al., 2015), that is, the transport of material to the surface is assumed to be controlled by three different resistances: the aerodynamic resistance $\left(R_{\mathrm{a}}\right)$, the quasi-laminar layer resistance $\left(R_{\mathrm{b}}\right)$, and the surface resistance $\left(R_{\mathrm{c}}\right)$. The surface resistance is regulated by the stomatal uptake, which relies on stomatal conductance, as well as external plant surfaces like the soil underlying the vegetation.

In this study, we improve the dry deposition scheme within the chemistry transport model CHIMERE considering the effect of soil water limitation to stomatal conductance. Our main aim was to perform several different simulations testing various hypotheses of water uptake by plants at different soil depths in the rooting zone, based on the main assumption 
that roots maximize water uptake to fulfill resource requirements adsorbing water at different depths depending on the water availability. Finally, we show and discuss the resulting effects on $\mathrm{O}_{3}$ dry deposition and concentration, in order to stress the need of a proper parameterization of root-depth soil moisture when evaluating the stomatal feedbacks on the atmosphere and for a thorough $\mathrm{O}_{3}$ risk assessment.

\section{Methodology}

\subsection{The multi-model framework}

We use a multi-model system to reproduce the meteorological conditions and the concentration of gases in the troposphere; this framework is composed by the WRF (Weather Research and Forecast Model) regional meteorological model and the CHIMERE chemistry transport model.

In this study, in order to have a large latitudinal gradient and assess the role of soil moisture across different climatic zones, we selected a domain extending over all of Europe (except Iceland). For both WRF and CHIMERE we performed a simulation for the whole year 2011, with a spin-up of 2 months to initialize all the fields.

\subsubsection{The meteorological model WRF}

Meteorological variables are simulated with the WRF regional model (v 3.6); it is a limited-area, non-hydrostatic, terrain-following eta-coordinate mesoscale model (Skamarock et al., 2008) widely used worldwide for climate studies. In our configuration, the model domain is projected on a regular latitude-longitude grid with a spatial resolution of $16 \mathrm{~km}$ and with 30 vertical levels extending from land surface to $50 \mathrm{hPa}$. The initial and boundary meteorological conditions required to run the WRF model are provided by the European Centre for Medium-Range Weather Forecast (ECMWF) analyses with a horizontal resolution of $0.7^{\circ} \mathrm{ev}-$ ery $6 \mathrm{~h}$ (Dee et al., 2011).

The exchange of heat, water and momentum between soil, vegetation and atmosphere is calculated using the Noah land surface model (Chen and Dudhia, 2001); in our configuration the soil has a vertical profile with a total depth of $2 \mathrm{~m}$ below the surface and it is partitioned into four layers with thicknesses of $10,30,60$, and $100 \mathrm{~cm}$ (giving a total of $2 \mathrm{~m}$ ). The root zone is fixed at $100 \mathrm{~cm}$ (i.e. including the top three soil layers). Thus, the lower $100 \mathrm{~cm}$ of soil layer acts as a reservoir with gravity drainage at the bottom (Al-Shrafany et al., 2014).

For each soil layer Noah calculates the volumetric soil water content $(\theta)$ from the mass conservation law and the diffusivity form of Richards' equation (Chen and Dudhia, 2001):

$$
\frac{\partial \theta}{\partial t}=\frac{\partial \theta}{\partial z}\left(D \frac{\partial \theta}{\partial z}\right)+\frac{\partial K}{\partial z}+F_{\theta},
$$

where $D$ is the soil water diffusivity, $K$ is the hydraulic conductivity, $F_{\theta}$ represents additional sinks and sources of water (i.e. precipitation, evaporation and runoff), $t$ is time and $z$ is the soil layer depth (Chen and Dudhia, 2001; Al-Shrafany et al., 2014; Greve et al., 2013). Integrating Eq. (1) over four soil layers and expanding $F_{\theta}$, we can calculate the volumetric soil water content for each soil layer (Chen and Dudhia, 2001; Al-Shrafany et al., 2014):

$$
\begin{aligned}
& d_{z 1} \frac{\partial \theta_{1}}{\partial t}=-D\left(\frac{\partial \theta}{\partial z}\right)_{z 1}-K_{z 1}+P_{d}-R-E_{\mathrm{dir}}-E_{t 1}, \\
& d_{z 2} \frac{\partial \theta_{2}}{\partial t}=D\left(\frac{\partial \theta}{\partial z}\right)_{z 1}-D\left(\frac{\partial \theta}{\partial z}\right)_{z 2}+K_{z 1}-K_{z 2}-E_{t 2}, \\
& d_{z 3} \frac{\partial \theta_{3}}{\partial t}=D\left(\frac{\partial \theta}{\partial z}\right)_{z 2}-D\left(\frac{\partial \theta}{\partial z}\right)_{z 3}+K_{z 2}-K_{z 3}-E_{t 3}, \\
& d_{z 4} \frac{\partial \theta_{4}}{\partial t}=D\left(\frac{\partial \theta}{\partial z}\right)_{z 3}+K_{z 3}-K_{z 4},
\end{aligned}
$$

where $d_{z i}$ is the thickness of the $i$ th soil layer, $P_{d}$ is the precipitation not intercepted by the canopy, $E_{\mathrm{t} i}$ represents the canopy transpiration taken by the canopy root in the $i$ th layer within the root zone, $E_{\text {dir }}$ is the direct evaporation from the top surface soil layer, and $R$ is the surface runoff, calculated using the Simple Water Balance (SWB) model (Schaake et al., 1996). In the deeper soil layer (i.e. fourth) the hydraulic diffusivity is assumed to be zero, so that the soil water flux is due only to the gravitational percolation term $K_{z 4}$ (i.e. drainage). A full and detailed description of the abovementioned parameterizations used by the Noah scheme can be found in Chen and Dudhia (2001).

For the definition of vegetation and land cover WRF uses the United States Geological Survey (USGS) land cover dataset, which has a resolution of $1 \mathrm{~km}$ with 24 categories (Loveland et al., 2000; Hibbard et al., 2010; Sertel et al., 2010); this land cover dataset is derived from the $1 \mathrm{~km}$ satellite Advanced Very High Resolution Radiometer (AVHRR) data. In addition to land cover, WRF defines 12 soil types and 4 non-soil types, including organic material, water, bedrock, and ice. Soil types are classified based on the percentage of sand, silt, and clay in the soil (Dy and Fung, 2016); for each soil type, WRF has a default soil parameter table that generalizes the hydraulic and thermal properties of the soil. Soil texture data are derived from the Food and Agriculture Organization (FAO) 5 min soil type categories.

One useful capability of WRF is its flexibility in choosing different dynamical and physical schemes; Table 1 lists the main options used in this study for physical schemes.

\subsubsection{The chemistry transport model CHIMERE}

The chemistry transport model used in this study is CHIMERE (v2014b), an Eulerian model developed to simulate gas-phase chemistry, aerosol formation, transport and deposition at a regional scale (Menut et al., 2014). 
Table 1. WRF 3.6 physical configurations used in the model simulations.

\begin{tabular}{lll}
\hline Process & Configuration & Reference \\
\hline Microphysics & Single Moment-3 class (mp_physics = 3)* & Hong et al. (2004) \\
Cumulus parameterization & Kain-Fritsch $($ cu_physics =1)* & Kain (2004) \\
Shortwave radiation & RRTM (ra_sw_physics =1)* & Mlawer et al. (1997) \\
Longwave radiation & RRTM (ra_lw_physics =1)* & Mlawer et al. (1997) \\
Land surface & Noah land model (sf_surface_physics = 2)* & Chen and Dudhia (2001) \\
Planetary boundary layer & YSU (bl_pbl_physics =1)* & Hong et al. (2006) \\
\hline
\end{tabular}

* A complete description of parameterizations and model flags is given in the WRF 3 user guide

(http://www2.mmm.ucar.edu/wrf/users/docs/user_guide_V3.6/ARWUsersGuideV3.6.1.pdf, last access: 20 April 2018)

The gas-phase chemical mechanism used by CHIMERE is MELCHIOR2 (Lattuati, 1997), which consists of a simplified version (40 chemical species, 120 reactions) of the full chemical mechanism MELCHIOR; this latter mechanism describes more than 300 reactions of 80 species. Photolysis rates are explicitly calculated using the FastJ radiation module (Wild et al., 2000), as described by Mailler et al. (2016, 2017). External meteorological forcing required by CHIMERE to calculate the atmospheric concentrations of gas-phase and aerosol species are directly provided by the WRF simulation. In addition, to accurately reproduce the gas-phase chemistry, emissions must be provided every hour for the specific species of the chemical mechanism. For studies over Europe, the EMEP inventory (Vestreng et al., 2009) is usually used for anthropogenic emissions of $\mathrm{NO}_{x}$, $\mathrm{CO}, \mathrm{SO}_{2}, \mathrm{PM}_{2.5}$ and $\mathrm{PM}_{10}$. Biogenic emissions of six species (isoprene, $\alpha$-pinene, $\beta$-pinene, limonene, ocimene, and NO) are calculated through the MEGAN model (Guenther et al., 2006). This model parameterizes the bulk effect of changing environmental conditions using three time-dependent input variables: surface air temperature, radiation and foliage density (i.e. leaf area index, LAI). In the standard version of CHIMERE, the LAI database is given as a monthly mean product derived from MODIS observations, referred to base year 2000 (Menut et al., 2014). However, as climate change leads to a widespread greening of Earth surface (Zhu et al., 2016), a mean climatological LAI referred to year 2000 could not be adequate to correctly simulate biogenic emissions during our simulation (year 2011). Thus, here we replaced the original LAI data with mean monthly GIMMS-LAI3g data (Zhu et al., 2013) for the year 2011.

Boundary conditions are provided as a monthly climatology of the LMDz-INCA global chemistry transport model (Hauglustaine et al., 2004; Folberth et al., 2006) for gaseous species and the GOCART model (Ginoux et al., 2001) for aerosol species. More details regarding the parameterizations of the above-mentioned processes are described in Menut et al. (2014).

\subsubsection{Dry deposition: the $\mathrm{DO}_{3} \mathrm{SE}$ model}

Following Wesely (1989), within CHIMERE the dry deposition velocity is described through an electrical resistance analogy, that is, the transport of material from the lowest model layer to the surface is assumed to be dependent on three different resistances: the aerodynamic resistance $\left(R_{\mathrm{a}}\right)$, the quasi-laminar layer resistance $\left(R_{\mathrm{b}}\right)$, and the surface resistance $\left(R_{\mathrm{C}}\right)$. The total resistance to deposition of a gaseous species is therefore the sum of these three individual resistances and is, by definition, the inverse of the deposition velocity. Considering the surface resistance, it is modelled using a number of different other resistances accounting for both stomatal and non-stomatal fluxes (Menut et al., 2013). In this work we have only modified the stomatal resistance formulation within the surface resistance term; thus our modifications do not affect the other non-stomatal parameterizations.

The leaf-level stomatal conductance (i.e. the inverse of stomatal resistance) is estimated by CHIMERE using the $\mathrm{DO}_{3} \mathrm{SE}$ model (Emberson et al., 2000). As already mentioned above, this model integrates the effects of multiple climatic factors, vegetation characteristics and local features through some limiting functions (e.g. Emberson et al., 2000). The limiting functions consider the variation in the maximum stomatal conductance $\left(g_{\max }\right)$ with photosynthetic photon flux density $\left(f_{\text {light }}\right)$, surface air temperature $\left(f_{\text {temp }}\right)$ and vapour pressure deficit $\left(f_{\mathrm{VPD}}\right)$ (Mills et al., 2011; Büker et al., 2012); they vary between 0 and 1 , with 1 meaning no limitation to stomatal conductance (e.g. Emberson et al., 2000; Mills et al., 2011). In addition, the $\mathrm{DO}_{3} \mathrm{SE}$ model requires another function describing the phenology of vegetation $\left(f_{\text {phen }}\right)$; this function is used to compute the duration of growing season during which plants can uptake gases from atmosphere (Anav et al., 2017).

Here, we improve the $\mathrm{DO}_{3} \mathrm{SE}$ scheme within CHIMERE considering also the soil water content (SWC) limitation to stomatal conductance; the soil-water limitation function is defined as

$f_{\mathrm{SWC}}=\min \left[1, \max \left(f_{\min }, \frac{\mathrm{SWC}-\mathrm{WP}}{\mathrm{FC}-\mathrm{WP}}\right)\right]$, 
where WP and FC are the soil water content at wilting point and at field capacity, respectively; these two parameters are constant and depend on the soil type. Given the abovementioned limiting functions, the stomatal conductance is computed as follows:

$$
g_{\text {sto }}=g_{\text {max }} \cdot f_{\text {phen }} \cdot f_{\text {light }} \cdot \max \left(f_{\min }, f_{\text {temp }} \cdot f_{\mathrm{VPD}} \cdot f_{\mathrm{SWC}}\right) \text {, }
$$

where $g_{\max }$ is the maximum stomatal conductance of a plant species to $\mathrm{O}_{3}$ and $f_{\min }$ is the minimum stomatal conductance expressed as a fraction of $g_{\max }$ (Emberson et al., 2000).

Meteorological fields required by the $\mathrm{DO}_{3} \mathrm{SE}$ model, such as $2 \mathrm{~m}$ air temperature, relative humidity, shortwave radiation and soil moisture, are directly provided by WRF. As already discussed above, WRF computes soil moisture over four soil layers of different thicknesses. For the integrated risk assessment studies, some authors make use of $1 \mathrm{~m}$ soil layer to compute the stomatal $\mathrm{O}_{3}$ flux and dry deposition (e.g. Simpson et al., 2012), while other authors use a shallower soil moisture layer (e.g. De Marco et al., 2016) as most of the absorbing fine roots concentrate in the topsoil layer (Jackson et al., 1996; Vinceti et al., 1998). Here we perform five different simulations testing various hypotheses: (1) no soil moisture limitation to stomatal conductance (henceforth NO_SWC), (2) soil moisture from first soil layer (i.e. $0-10 \mathrm{~cm}$ depth, henceforth SWC_10cm), (3) soil moisture from middle soil (i.e. $10-40 \mathrm{~cm}$ depth, henceforth SWC_40 cm), (4) soil moisture from the deeper soil layer of rooting zone (i.e. $0.4-1 \mathrm{~m}$ depth, henceforth SWC_1m) and (5) a dynamic layer (henceforth SWC_DYN) supporting the hypothesis that plants adsorb water at the depth with the highest water content availability.

As the original version of CHIMERE does not account for any limitation of soil moisture to stomatal conductance, in the following analysis we use the simulation NO_SWC as reference; thus we show and discuss models' changes with respect to this original configuration (Menut et al., 2014).

\subsection{Measurement data and statistical analysis}

In order to assess how the new parameterization of dry deposition changes the ability of CHIMERE to reproduce the spatial distribution of surface $\mathrm{O}_{3}$ concentration, we compare the simulated data at surface level against in situ measurements. Station data were obtained from the European air quality database (AirBase) and maintained by the European Environment Agency (EEA) (http://acm.eionet.europa.eu/databases/ airbase/, last access: 20 April 2018).

For the validation of $\mathrm{O}_{3}$ bias, computed comparing hourly simulated $\mathrm{O}_{3}$ concentrations with AirBase data, we use the root-mean-square error (RMSE), while to assess the agreement in the phase (i.e. hourly cycle) we use the correlation coefficient.

Considering the soil moisture, we retrieve precipitation data over four forested eddy covariance sites belonging to the European flux network (http://www.europe-fluxdata.eu/, last access: 20 April 2018); a good representation of precipitation simulated by the model is mandatory to correctly reproduce the dynamics of water in the soil. The choice of these specific sites is due to the multiple requirements of having fullyear data coverage with different climatic zones. Specifically, the sites cover a continental climate typical of central Europe, where soil moisture barely limits the stomatal opening, and Mediterranean sites characterized by scarce water availability during summer months, highly limiting the stomatal opening. Unfortunately, although soil moisture is measured at these sites, the depth of measurements is not consistent with model's layers and it also does not reach the same depth of the model, thus making any comparison of the vertical distribution of water in the soil difficult.

\section{Results}

\subsection{Seasonal changes in soil water content}

Figure 1 shows the seasonal variation of simulated soil water content at four different locations; in order to assess the reliability of vertical soil moisture profiles we also evaluate models skills in capturing precipitation events by comparing the hourly simulated precipitation with data collected over the four measurement stations.

The first site, Leinefelde in Germany, is characterized by a temperate/continental climate with mean annual precipitation ranging between 700 and $750 \mathrm{~mm}$, covered by a beech forest (Fagus sylvatica). Overall, compared to in situ observations, WRF reproduces both the rainfall events and their intensity well (Fig. 1a). Considering the soil moisture, at the beginning of the year, the soil is at field capacity, and rapidly becomes saturated down to $40 \mathrm{~cm}$, while below $1 \mathrm{~m}$ depth from the end of January to mid-April the soil is close to the field capacity. After mid-April, soil remarkably dries out at all depths, and water content oscillates between 0.28 and $0.36 \mathrm{~m}^{3} \mathrm{~m}^{-3}$ until October, when decreasing evaporative demand and weak rain events caused a transient partial recovery around $0.33 \mathrm{~m}^{3} \mathrm{~m}^{-3}$. Then, the new rainfall events at the end of November lead to rising soil water content above the field capacity until the end of the year (Fig. 1a).

The second temperate site, covered by a spruce forest (Picea abies), is Oberbärenburg in Germany; it is characterized by a mean annual precipitation of about $1000 \mathrm{~mm}$. It is worth noting that WRF captures most of the rainfall events, despite the fact that it slightly underestimates their intensity during the period May-August. Here, in the rooting zone, the soil is constantly above the field capacity and near saturation until mid-March; then it rapidly drains, and soil water content remains in the range $0.24-0.26 \mathrm{~m}^{3} \mathrm{~m}^{-3}$, with short-term increases following precipitation events, until December, when it increased to above $0.28 \mathrm{~m}^{3} \mathrm{~m}^{-3}$ (Fig. 1b).

In Collelongo, a Fagus sylvatica mountain forest site in central Italy, the mean annual precipitation is about 

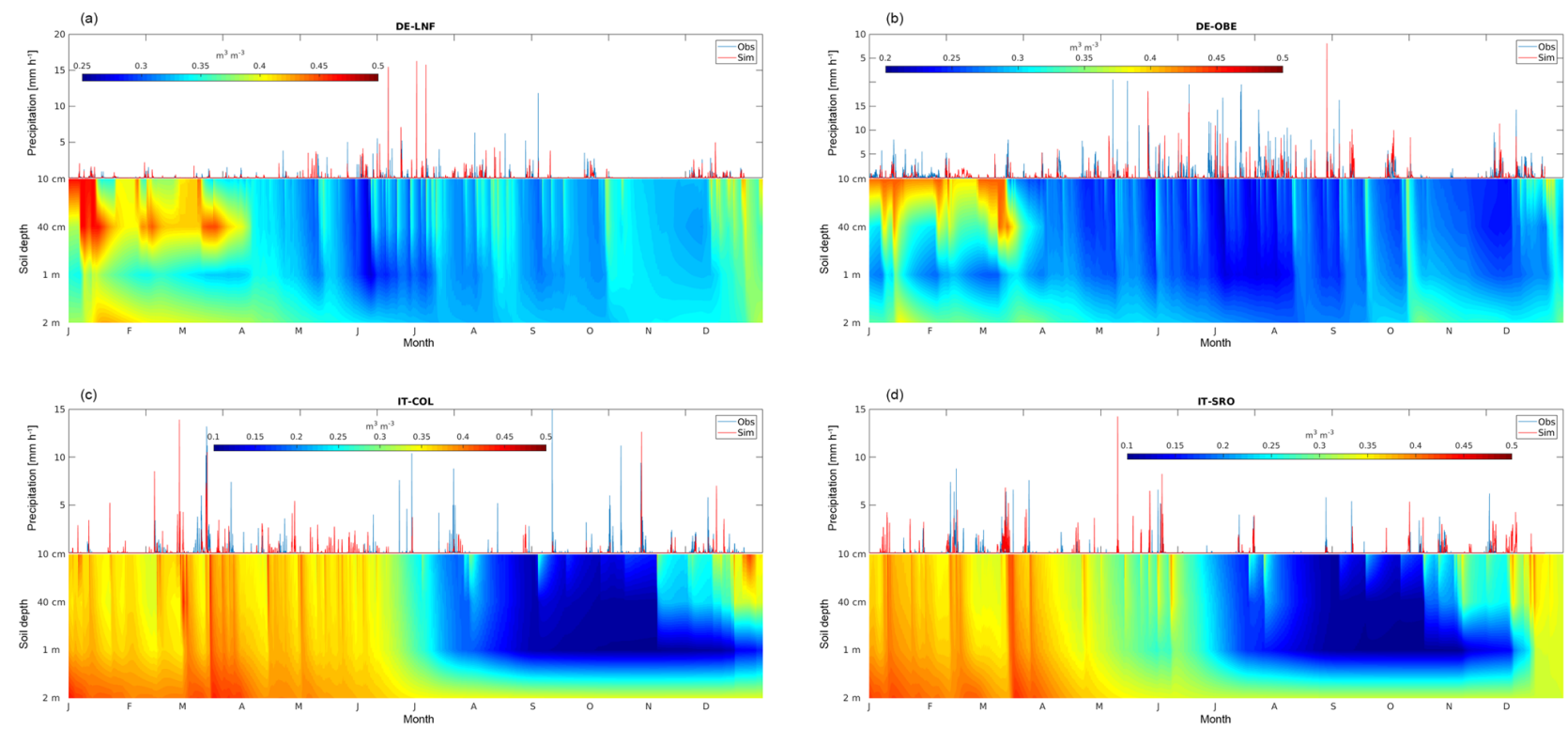

Figure 1. Comparison of hourly precipitation simulated by WRF with observations collected at four measurement sites along with changes in the vertical distribution of soil moisture $\left(\mathrm{m}^{3} \mathrm{~m}^{-3}\right)$ during the year.

$1200 \mathrm{~mm}$. From the beginning of the year to the end of June, the soil water content is above $0.3 \mathrm{~m}^{3} \mathrm{~m}^{-3}$, with short-term increases above field capacity from $10 \mathrm{~cm}$ to $1 \mathrm{~m}$ and a stable content above field capacity below $1 \mathrm{~m}$ depth; then, in July, soil moisture progressively decreases to about $0.20 \mathrm{~m}^{3} \mathrm{~m}^{-3}$ with a short-term rainfall resupply at the end of the month. From August to November, because of high evapotranspiration rates and weak precipitation events, soil moisture sharply drops to $0.15 \mathrm{~m}^{3} \mathrm{~m}^{-3}$ or less, and, at $1 \mathrm{~m}$ depth, it appears to have been constantly at wilting point from the end of September to early November. Finally, in December, soil moisture rapidly increases in the upper layers, reaching near saturation in late December, but remains low around $1 \mathrm{~m}$ depth until the end of the year (Fig. 1c).

The fourth station is San Rossore, a Mediterranean Pinus spp. forest located on the coastal region of central Italy and characterized by a mean annual precipitation of $920 \mathrm{~mm}$. Here the pattern is substantially similar to Collelongo: soil water content is lower in spring, when rainfall infiltrates faster and deeper and less water is retained; then the autumn drought at $1 \mathrm{~m}$ depth is less pronounced and of shorter duration, but water recharge towards the end of the year was again slower (Fig. 1d).

Overall, these results suggest that soil water availability was higher from April to September for the two central European sites, where soil water content remained above $50 \%$ of total available water capacity. In the Mediterranean sites, water availability declined from spring onwards, but remained above $40 \%$ total available water capacity until late August, while effective drought conditions occurred in October.

\subsection{Changes in $\mathrm{O}_{3}$ dry deposition}

The inclusion of soil water limitation in the stomatal conductance parameterization firstly affects the surface resistance, which in turn affects the dry deposition velocity and thus the amount of air pollutants removed from the surface layer by dry deposition (Seinfeld and Pandis, 2016; Hardacre et al., 2015; Monks et al., 2015). Figure 2 shows the mean percentage change in $\mathrm{O}_{3}$ dry deposition during the periods April-May-June (AMJ) and July-August-September (JAS) between the reference simulation (i.e. NO_SWC) and the simulations that take into account the soil moisture limitation to stomatal conductance. Clearly, as the inclusion of soil water stress leads to a reduction in stomatal conductance, the amount of $\mathrm{O}_{3}$ removed by dry deposition is always larger in the NO_SWC simulation than in the other simulations; this explains the negative pattern in the percentage change in $\mathrm{O}_{3}$ dry deposition in both the analysed seasons. Looking at the spatial pattern (Fig. 2), we find the weaker differences in Norway, where soil moisture is barely limiting the stomatal conductance, while the larger differences occur in the Mediterranean Basin (i.e. Spain, southern France, Italy, Greece and Turkey). In fact, in these semi-arid regions the soil dries out quickly, especially during summer (Fig. 1), and plants close their stomata during the warmer hours of the day to prevent water loss, leading to a smaller amount of $\mathrm{O}_{3}$ entering the leaves and thus removed by vegetation. This process is well displayed during JAS in the SWC_ $10 \mathrm{~cm}$ simulation and to a lesser extent in the SWC_40 cm, SWC_1m and SWC_DYN simulations: specifically, in southern Europe the upper soil layer (i.e. $10 \mathrm{~cm}$ ) dries out faster than the deeper ones during 
$\%$ change, AMJ SWC $10 \mathrm{~cm}$
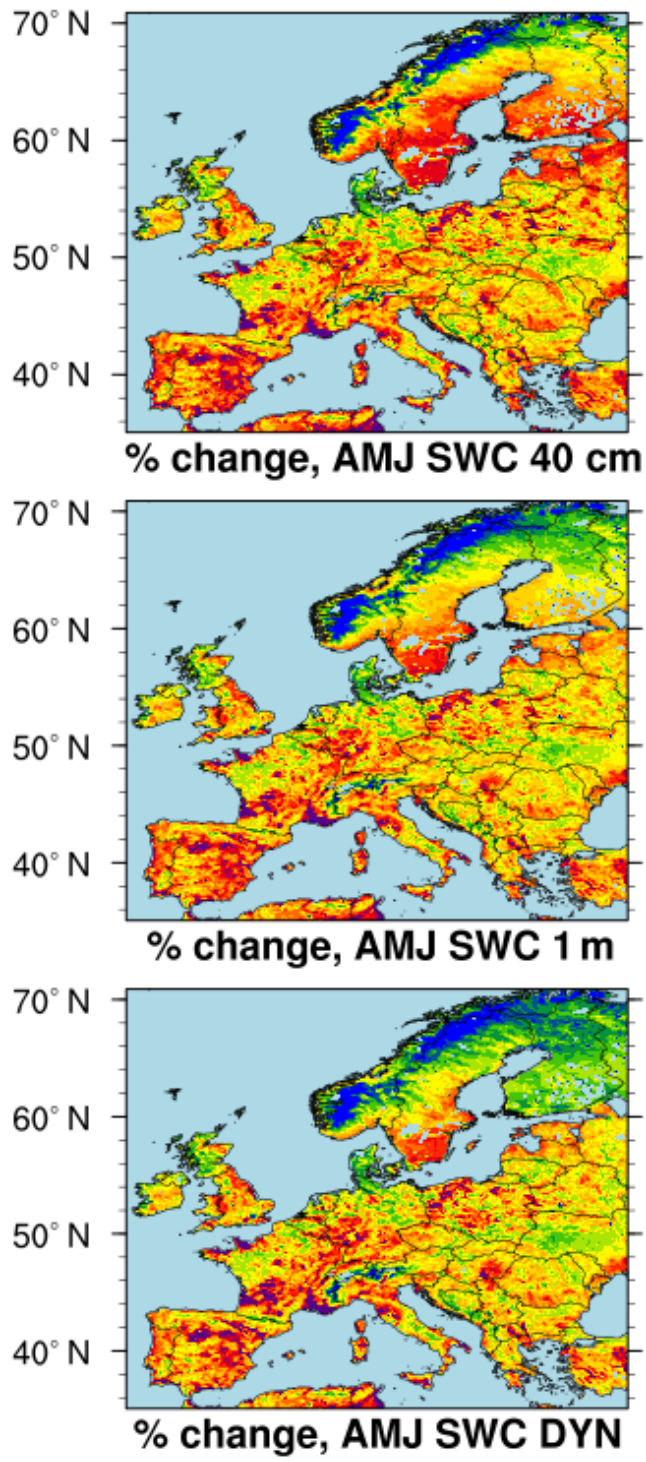

$70^{\circ} \mathrm{N}$

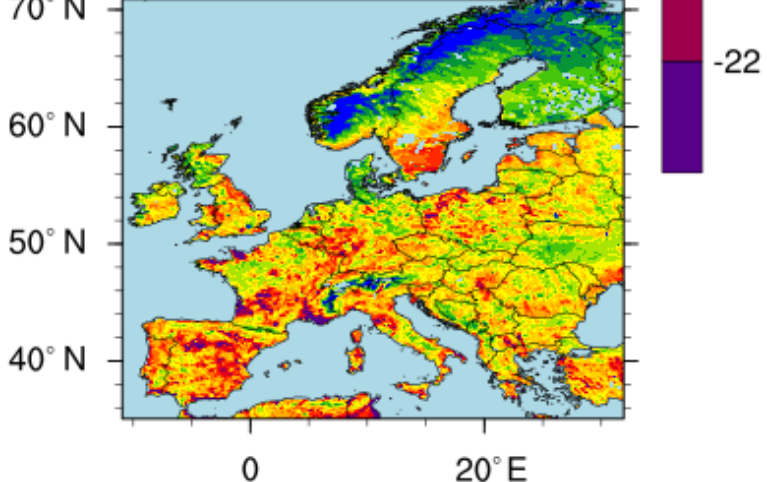

$\%$ change, JAS SWC $10 \mathrm{~cm}$

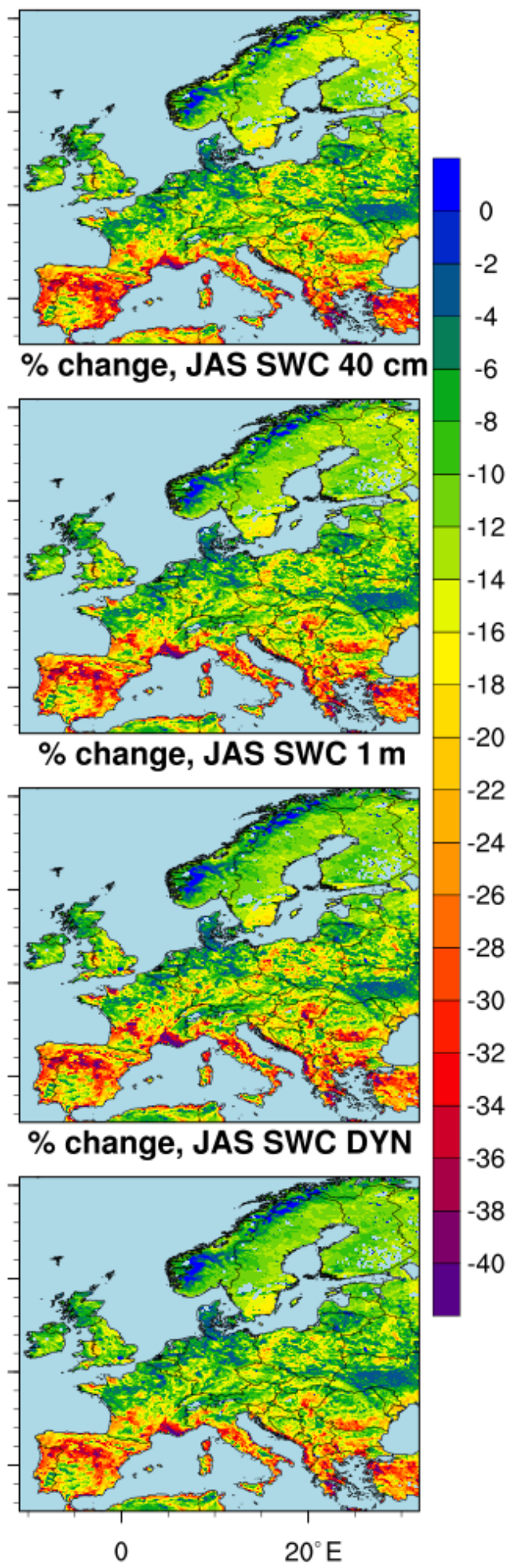

Figure 2. Percentage change in the amount of $\mathrm{O}_{3}$ removed by dry deposition over the land points (sea points are masked) computed in the time periods April-May-June (AMJ) and July-August-September (JAS). The percentage change is defined as [(Sim-Ref) $/$ Ref)] $\times 100$, where Ref is the NO_SWC simulation and Sim represents the other simulations. A percentage change of $25 \%$ corresponds to about $6 \mathrm{~kg}$ $\mathrm{O}_{3} \mathrm{~m}^{-2} \mathrm{~d}^{-1}$. 


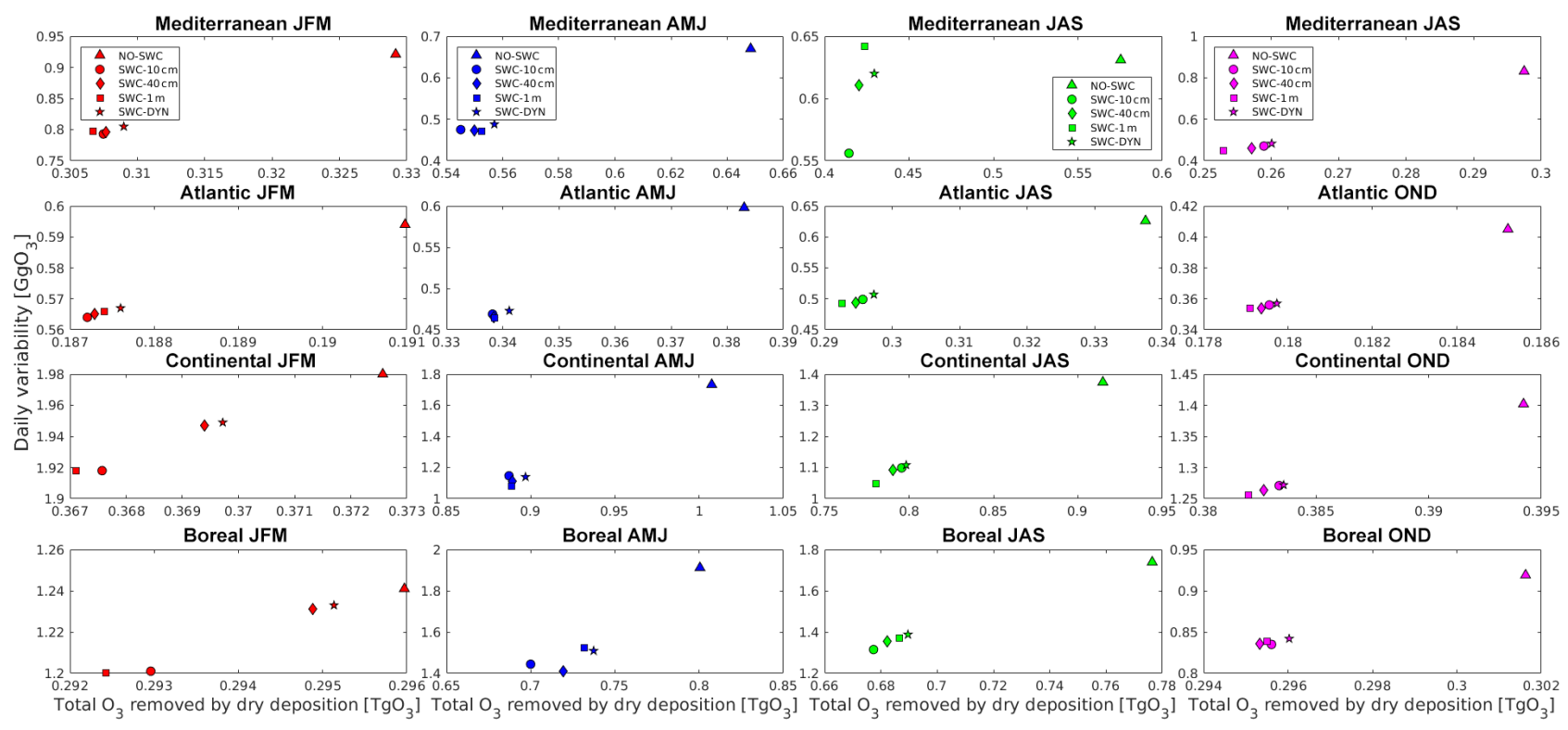

Figure 3. Comparison of seasonal amount of $\mathrm{O}_{3}$ removed by dry deposition spatially integrated over climatic regions (https://www.eea. europa.eu/data-and-maps/data/biogeographical-regions-europe-3, last access: 20 April 2018) along with standard deviation of daily data.

the warm and dry season, consequently, in the SWC_10 $10 \mathrm{~cm}$ simulation we find the stronger limitation of soil moisture to stomatal conductance and the highest reduction in $\mathrm{O}_{3}$ dry deposition. In the other simulations we use a deeper rooting zone where plants can uptake water from the soil; during summer these layers are generally moister than the shallow layer, and thus the stomatal conductance will be less limited by soil moisture and consequently the vegetation removes a larger amount of $\mathrm{O}_{3}$.

In addition, in order to point out the seasonal changes between different climatic zones, in Fig. 3 we show the dry deposition integrated over different domains along with its daily variability. As already discussed above, for all the seasons and climatic regions, the NO_SWC simulation shows the largest amount of $\mathrm{O}_{3}$ removed by dry deposition, followed by the SWC_DYN experiment. Interestingly, over different domains and seasons the SWC_1m simulation exhibits the lowest dry deposition, suggesting that in some regions and seasons the shallow layers are often wetter than deeper layers. This is due to weak and sparse rainfall events which are unable to wet the deeper layers (Fig. 1). Thus, this pattern sheds light on the importance of using a dynamic layer in chemistry models.

Furthermore, it is noteworthy how the inclusion of soil water limitation changes not only the amount of pollutant removed by deposition but also its variability; specifically, in all the domains and seasons (except the Mediterranean area during summer) we found a relevant reduction in the standard deviation of daily $\mathrm{O}_{3}$ dry deposition in simulations accounting for soil moisture limitation on stomatal opening (Fig. 3). This pattern mainly depends on the lower variability of the soil water function (i.e. $f_{\mathrm{SWC}}$ ) respect to the air humidity and air temperature functions (i.e. $f_{\mathrm{VPD}}$ and $f_{\mathrm{temp}}$ ). In fact, at a regional scale, the soil moisture exerts a strong control on stomatal conductance (Mészáros et al. 2009; Anav et al., 2016), so that the variability of the stomatal opening is more regulated by the variability of soil moisture than by the other physical variables (see Eq. 7). However, the changes in the daily variability are still unclear for some regions and simulations and deserve further analyses.

Overall, during the whole year the amount of $\mathrm{O}_{3}$ removed by dry deposition (sum of stomatal and non-stomatal deposition) integrated over the only land points of the domain is $8.568 \mathrm{TgO}_{3}$ in the NO_SWC simulation, 7.576 $\mathrm{TgO}_{3}$ $(-11.8 \%)$ in the $\mathrm{SWC}_{-} 10 \mathrm{~cm}, 7.618 \mathrm{TgO}_{3}(-11.1 \%)$ in the SWC_40cm, $7.617 \mathrm{TgO}_{3}(-11.1 \%)$ in the SWC_1m, and $7.693 \mathrm{TgO}_{3}(-10.2 \%)$ in the SWC_DYN.

\subsection{Changes in $\mathrm{O}_{3}$ concentration}

As plants uptake atmospheric gases into the leaves when stomata are open (Cieslik et al., 2009), changes in stomatal behaviour (and thus in dry deposition velocity) affect, in turn, the concentration of compounds remaining in the lower atmosphere; Fig. 3 shows the mean percentage change in $\mathrm{O}_{3}$ concentration in the lowest model layer (20-25 $\mathrm{m}$ in our case) between the reference simulation (i.e. NO_SWC) and the other simulations. Unlike Fig. 2, where we found a systematic negative percentage change in the amount of $\mathrm{O}_{3}$ removed by dry deposition, Fig. 3 shows a systematic positive percentage change, i.e. a higher concentration of $\mathrm{O}_{3}$ remaining in the atmosphere in the simulations where soil moisture limits the stomatal conductance. In addition, the higher (i.e. more neg- 


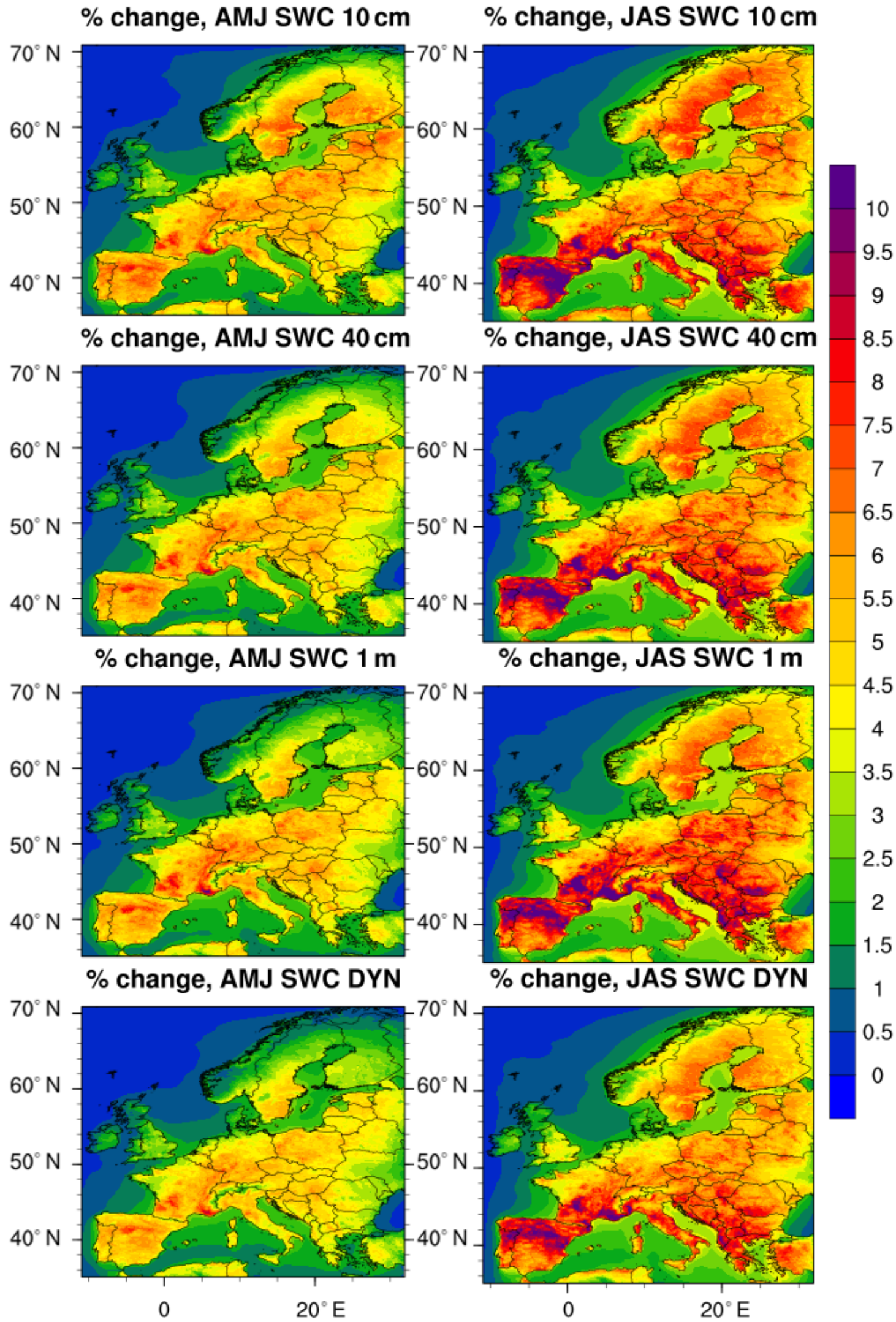

Figure 4. Percentage change in surface $\mathrm{O}_{3}$ concentration (absolute values are given in Fig. 5). 
ative) the percentage change of $\mathrm{O}_{3}$ removed by deposition, the more the concentration of $\mathrm{O}_{3}$ remaining in the air: Fig. 3 clearly shows how the larger differences in surface $\mathrm{O}_{3}$ concentration are found during summer (JAS) in the $S W C_{-} 10 \mathrm{~cm}$ simulation, i.e. the experiment where soil moisture plays the strongest limitation to stomatal conductance.

Similarly, the vertical mixing in surface layers, largely driven by wind and its interaction with frictional drag at the surface (Monks et al., 2015), propagates the changes in $\mathrm{O}_{3}$ concentration from the surface layer to upper layers. Figure 4 shows the $\mathrm{O}_{3}$ anomaly between the reference simulation and the simulations with soil water limitation, averaged over the plant growing season, i.e. April-September (Anav et al., 2017); here we show only grid points with a significant change in $\mathrm{O}_{3}$ concentration ( $t$ test, $95 \%$ confidence), while we mask out points where the anomaly is not significant. The larger anomaly in $\mathrm{O}_{3}$ concentration (up to $4 \mathrm{ppb}$ ) is found in the whole Mediterranean Basin for the SWC_10 cm simulation; interestingly, the anomaly is significant in almost all the grid points except Ireland and Scotland, which are characterized by high soil moisture levels even during summer, and up to $800 \mathrm{hPa}$, where we find an $\mathrm{O}_{3}$ anomaly larger than $1 \mathrm{ppb}$.

\subsection{Changes in the model performances}

As discussed above, the inclusion of soil water limitation to stomatal conductance leads to increased $\mathrm{O}_{3}$ concentration due to the reduced dry deposition rates; this clearly affects the model performances in reproducing both the phase and amplitude of hourly $\mathrm{O}_{3}$ concentration. Therefore, here we validate the simulated $\mathrm{O}_{3}$ against AirBase measurements.

Figure 6 (upper panels) shows how the inclusion of the new parameterization leads to an increase of model-data misfit during the temporal period April-September, being the percentage change in RMSE positive in all the stations. Overall, the mean RMSE (average over all the stations) computed comparing hourly data is $17.8 \mathrm{ppb}$ for the NO_SWC simulation, $19.5 \mathrm{ppb}$ in the $\mathrm{SWC}_{-} 10 \mathrm{~cm}$ and $\mathrm{SWC}_{-} 40 \mathrm{~cm}$, and $19 \mathrm{ppb}$ in the SWC_1m and SWC_DYN simulations.

Conversely, the new parameterization improves the model skills in reproducing the observed hourly cycle (Fig. 6, lower panels), being the percentage change in correlation coefficient positive in all the stations. Overall, the mean correlation computed from hourly data is 0.6 for the NO_SWC simulation, 0.62 in the SWC_10 $10 \mathrm{~cm}$ and 0.64 in the $\mathrm{SWC}_{-} 40 \mathrm{~cm}$, SWC_1m and SWC_DYN simulations.

This result is in agreement with a previous study which showed how, within CHIMERE, the deposition not only acts as a shifting term on the modelled concentration but also influences the variability and timing of ozone (Solazzo et al., 2017).

\section{Summary and conclusion}

In this study, we incorporated the soil moisture limitation into the dry deposition parameterization of CHIMERE model and tested different hypotheses of water uptake by roots. Model simulations with the improved parameterization indicate that $\mathrm{O}_{3}$ dry deposition significantly declines when soil moisture regulates the stomatal opening, particularly in southern Europe, where soil is close to the wilting point during the dry summer. This mechanism, occurring within the soil, in turn, affects the concentration of gases remaining into the lower atmosphere and, considering the vertical mixing in the boundary layer and the long-lived species such as $\mathrm{O}_{3}$, has an impact on $\mathrm{O}_{3}$ concentration extending from the plants canopy to the upper troposphere and decreasing with height; the influence on $\mathrm{O}_{3}$ concentration then quickly vanishes above the boundary layer, becoming no longer significant above $650 \mathrm{hPa}$.

The analysis of simulated soil moisture suggests that actual water availability from April to September, even in the Mediterranean sites, is higher than conventionally assumed; according to Allen et al. (1998) and Martínez-Fernández et al. (2015), soil water content values corresponding to $40-50 \%$ of total available water (TAW, FC-WP) often correspond to low stress conditions for cultivated plants. As the stress threshold lowers with rooting depth (Allen et al., 1998), it appears likely that the effect of water deficit on forest vegetation is limited in these conditions. As the effect of soil water content on stomatal aperture in the modified $\mathrm{DO}_{3} \mathrm{SE}$ model is modelled as a linear function of SWCWP (Eq. 6), it is possible that the actual reduction in stomatal conductance is overestimated for SWC values above 40$50 \%$ of TAW, i.e. the most common condition predicted by WRF in the April-September period over the analysed sites.

With the modified parameterization, CHIMERE shows increased bias in the prediction of surface hourly $\mathrm{O}_{3}$ concentrations across Europe with improved representation of the phase of the hourly cycle; this suggests that the inclusion of this new processes in the model does not lead to an univocal improvement of its performances. In fact, the new parameterization increases the well-known systematic overestimation of $\mathrm{O}_{3}$ concentrations (e.g. Anav et al., 2016), which derives from initial and lateral boundary conditions provided by the global chemistry transport model LMDz-INCA that overestimate the observed background concentrations (Terrenoire et al., 2015) as well as from the large uncertainties in other physical and chemical processes included in the model.

It should also be noted that the model comparison to satellite retrievals is not obvious in this study: here, we mainly focus on $\mathrm{O}_{3}$ changes in the boundary layer and lower troposphere, which correspond to the part of the atmosphere where satellite data are not robust: as shown by Boynard et al. (2016), the $\mathrm{O}_{3}$ vertical profiles inversions begin to be efficient in the upper troposphere and in the stratosphere, where our changes become negligible. Therefore, it would be largely uncertain to extract the signal close to the surface and 


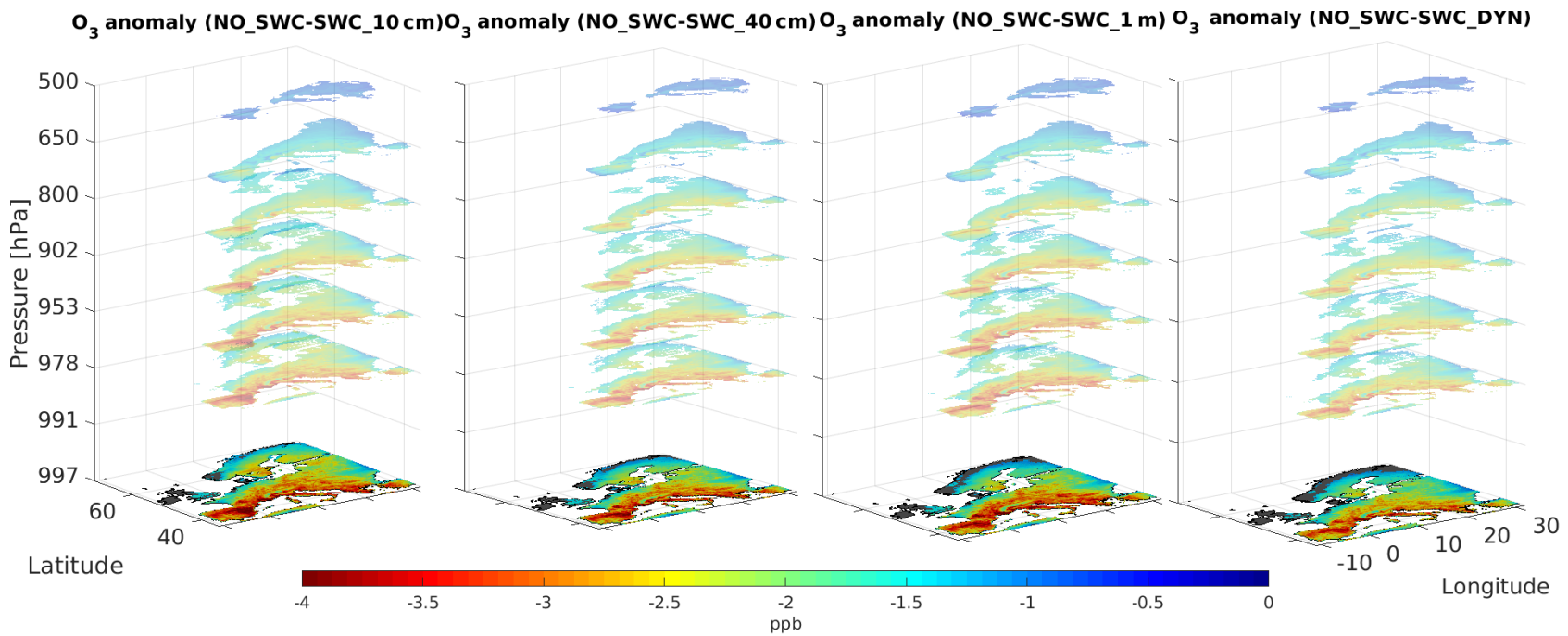

Figure 5. Vertical anomaly in $\mathrm{O}_{3}$ concentration computed during the time period April-September.

(a)

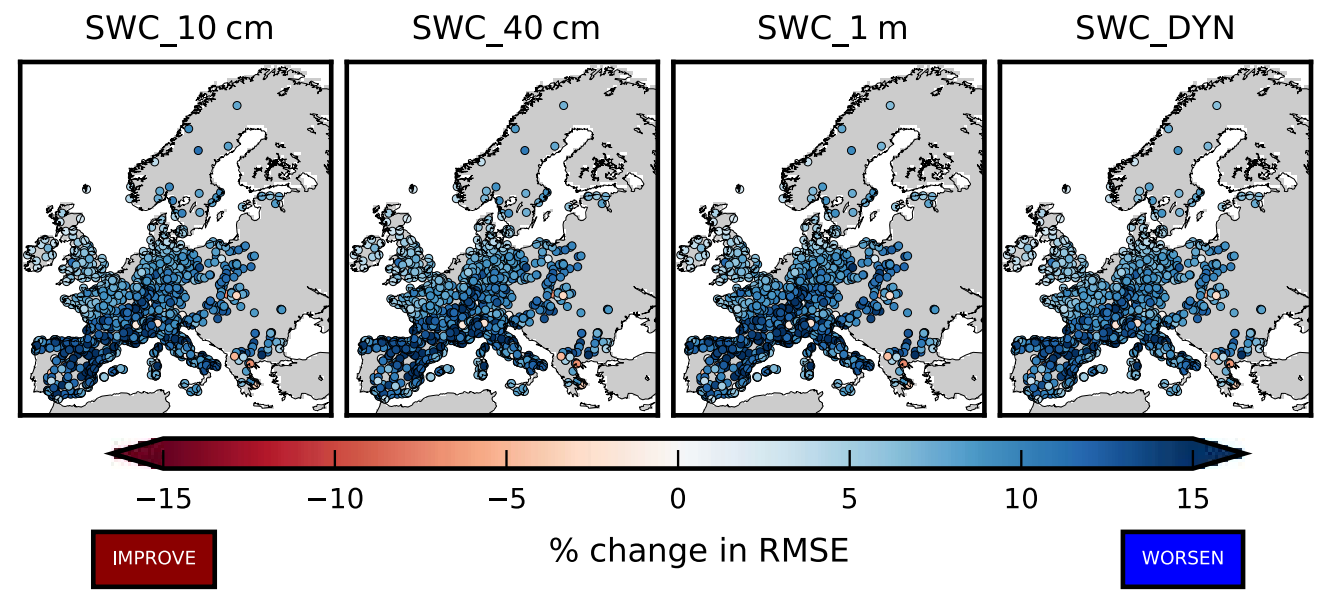

(b)

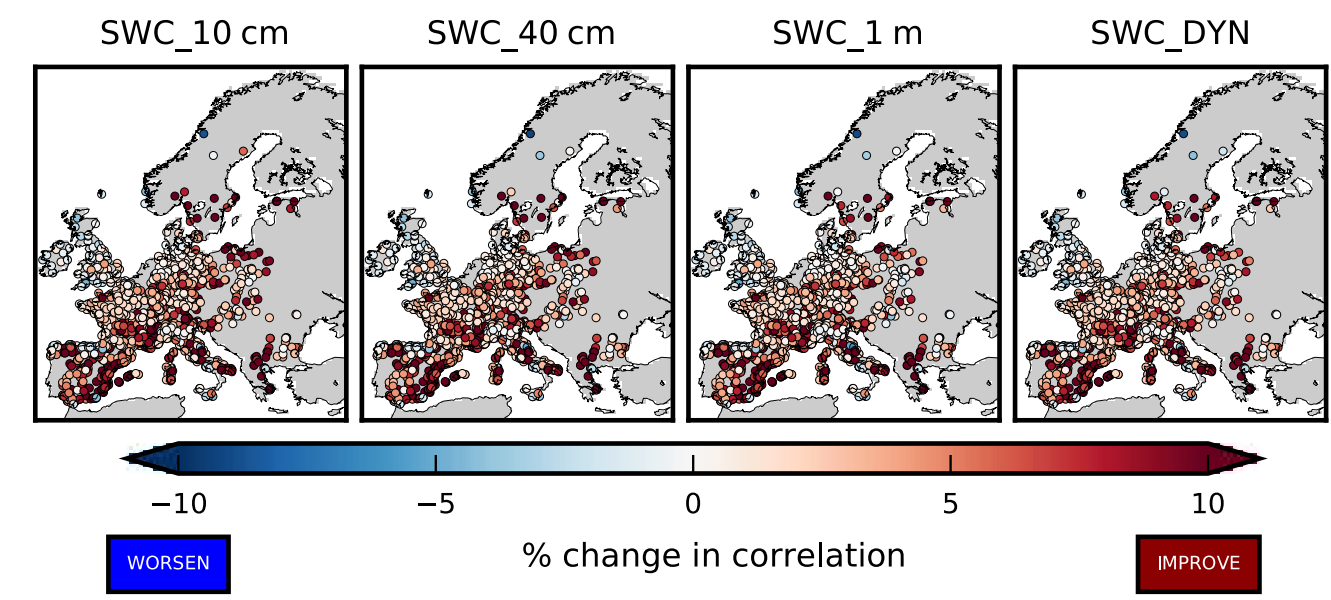

Figure 6. Percentage change in RMSE (a) and correlation coefficient (b) computed using hourly data in the time period April-September. The reference simulation is NO_SWC. 

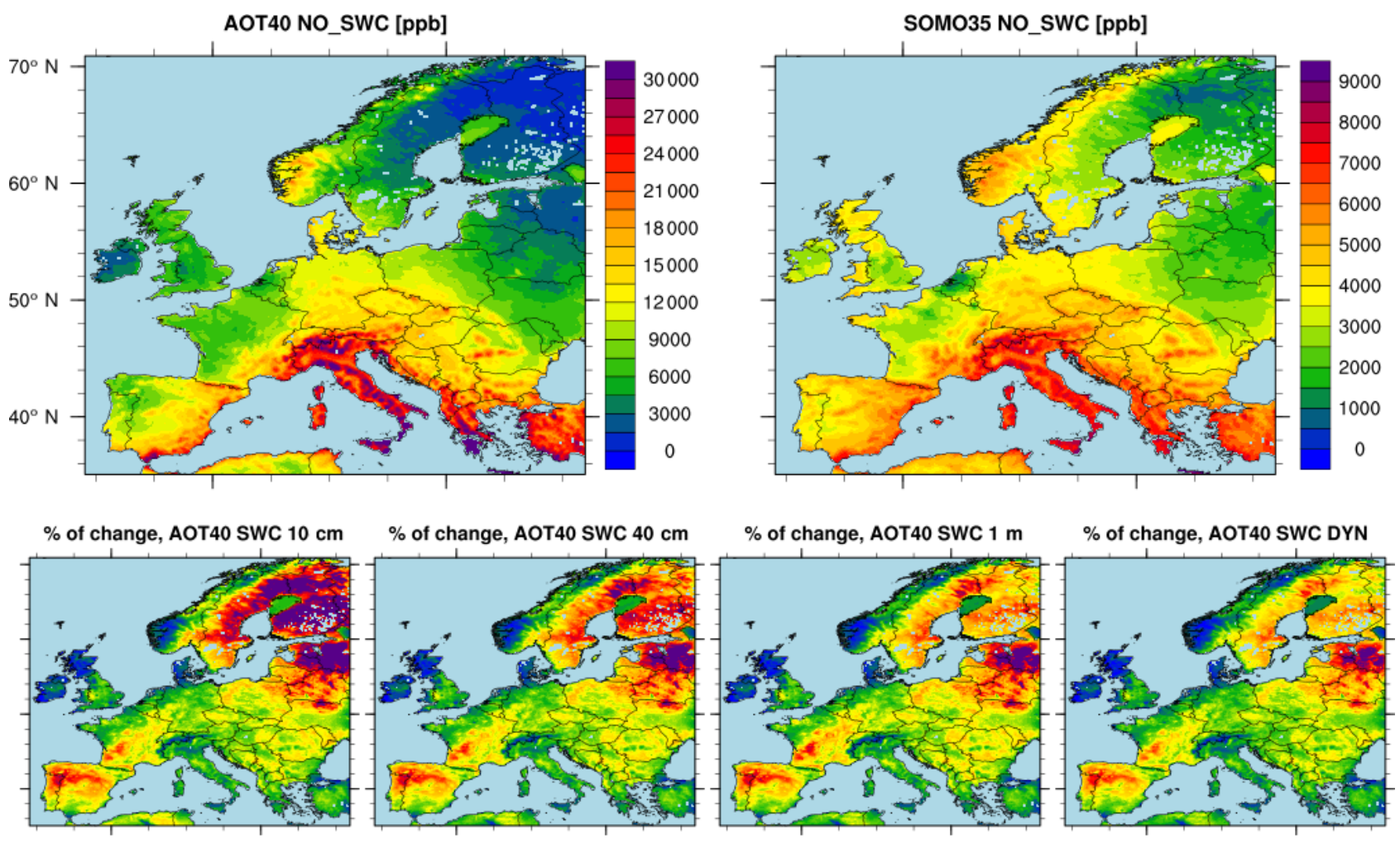

\begin{tabular}{llllllllllllllllll|l|l|l|l|l|l}
10 & 14 & 18 & 22 & 26 & 30 & 34 & 38 & 42 & 46 & 50 & 54 & 58 & 62 & 66 & 70 & 74 & 78 & 82 & 86 & 90
\end{tabular}

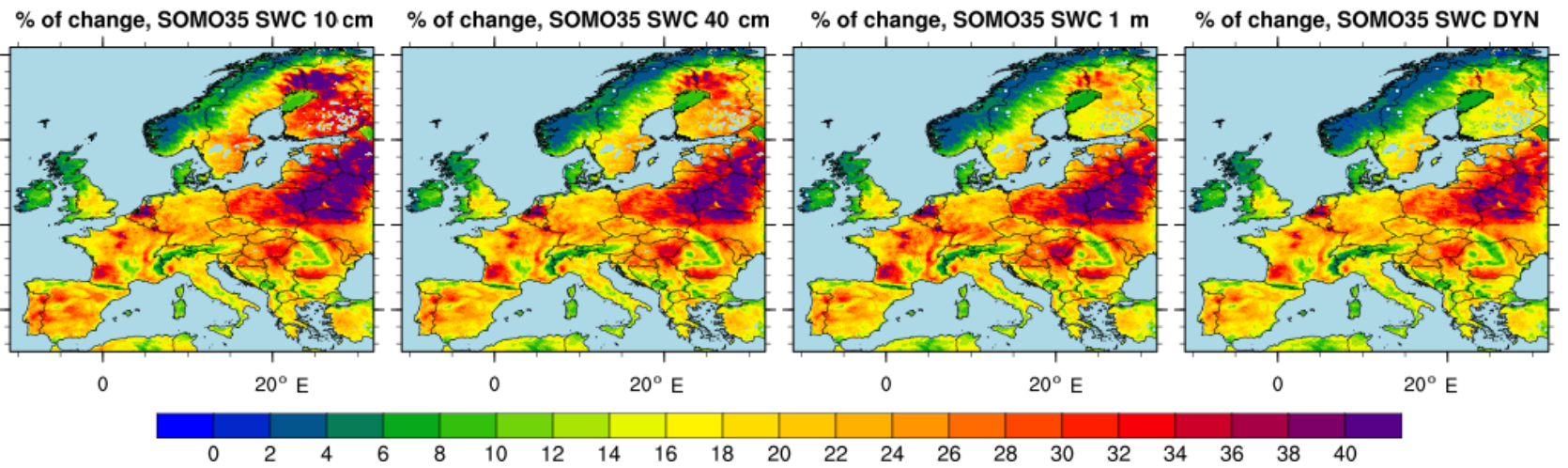

Figure 7. Spatial distribution of AOT40 and SOMO35 (upper panels) along with their percentage change (lower panels) computed using the NO_SWC simulation as reference. The AOT40 is defined as the accumulated amount of ozone over the threshold value of 40 ppb computed 30 September

during the vegetation growing season, i.e. AOT40 $=\int_{1 \text { April }} \max \left(\mathrm{O}_{3}-40,0\right) \mathrm{d} t$. Similarly, SOMO35 is defined as the yearly sum of the daily maximum of $8 \mathrm{~h}$ running average $\left(A_{8}^{d}\right)$ over $35 \mathrm{ppb}$ : SOMO35 $=\int_{d=1 \text { January }}^{d=31 \text { December }} \max \left(A_{8}^{d}-35,0\right)$.

assess how much our different hypotheses improved the total $\mathrm{O}_{3}$ column. Similarly, the comparison with vertical soundings would display the simulated vertical profiles very close each other.

However, in this study compared to former ones, generally the uncertainty in the dry deposition associated to soil moisture is relatively low (10-11\%), although it is above $30 \%$ in a few points. Schwede et al. (2011) compared two deposi- tion velocity models in two long-term monitoring networks in USA and Canada and found that the hourly median values of ozone, and therefore the flux, can be 2 or 3 times different depending on the deposition velocity model used. Similarly, Flechard et al. (2011) found differences between four dry deposition models by a factor of 2 or 3 for five atmospheric reactive nitrogen species $\left(\mathrm{NH}_{3}, \mathrm{HNO}_{3}, \mathrm{NO}_{2}\right.$, and aerosol $\mathrm{NH}_{4}^{+}$ and $\mathrm{NO}_{3}^{-}$) in a European monitoring network. Furthermore, 
Mészáros et al. (2009) pointed out that variation in surface resistance can involve differences in variability in total deposition velocity of up to 2 or 3 times, also indicating soil moisture as a key variable controlling the $\mathrm{O}_{3}$ dry deposition.

Moreover, our results are in agreement with Solazzo et al. (2017), which created a diagnostic methodology for model evaluation; using CHIMERE, they showed that setting the ozone dry deposition velocity to zero causes a profound change of the error structure of $\mathrm{O}_{3}$ concentration with significant impacts on not only the bias but also the variance and covariance terms (Solazzo et al., 2017). All these studies highlight that more sophisticated parameterizations of stomatal conductance are required in deposition models to reduce their uncertainty.

Finally, we point out that the uncertainty associated with different models or dry deposition schemes (or assumptions in rooting depth, as in this study) might have severe implications in the case of risk assessment for vegetation or human health. For instance, Fig. 7 shows the spatial distribution of the AOT40 (i.e. accumulated ozone over threshold of $40 \mathrm{ppb}$ ) and SOMO35 (sum of ozone means over $35 \mathrm{ppb}$ ), which are the two metrics used for vegetation and human health impact assessment over Europe. It should be noted that over eastern Europe the risk for vegetation can differ by up to $90 \%$ between the reference case (i.e. NO_SWC) and the simulation using a shallow rooting zone (i.e. $S W C \_10 \mathrm{~cm}$ ), while for the human health we report a difference exceeding $30 \%$ over large areas of Europe. This result clearly shows an amplification of the percentage change with respect to both $\mathrm{O}_{3}$ dry deposition and surface $\mathrm{O}_{3}$ concentrations. The amplification that we found in the risk assessment metrics is related to the fact that concentrations below $40 \mathrm{ppb}$ (in the case of AOT40) and $35 \mathrm{ppb}$ (for SOMO35) do not contribute to the final value of the metrics. In other terms, in eastern Europe, the $\mathrm{O}_{3}$ concentrations of the NO_SWC simulation do not exceed the threshold used by the two metrics and thus they do not contribute to their final value. Conversely, the other simulations have higher $\mathrm{O}_{3}$ concentrations because of the more limited stomatal conductance and, in these cases, the concentrations become larger than the threshold, causing an exponential rise in the value of the metrics compared to the reference case and thus an amplification of the percentage change. In the same way, in the Mediterranean area, where we showed the larger changes in $\mathrm{O}_{3}$ concentrations, we found a slight difference with respect to the reference case: in this region the $\mathrm{O}_{3}$ concentrations are already high enough to exceed the thresholds of the metrics, and thus the amplification is less evident than in eastern Europe.

Nevertheless, our results can be used to improve the representation of soil moisture stress on vegetation within chemistry transport models and to better describe the biogeochemical and biophysical feedbacks between the complex soilplant-atmosphere system in response to a changing climate toward warmer and drier conditions. As the soil water uptake is mainly related to different rooting systems (Wu et al.,
2017), chemistry models would benefit from the inclusion of species-specific parameterizations which ensure water uptake depending on species-specific eco-hydrological properties. In general, plants in water-limited regions can adapt to dry environments by accessing ground water (Craine et al., 2013) based on the depth and density of the root system (Wu et al., 2017), while deep-rooted forests can take up available water from deep soil during extreme drought events (Schwinning et al., 2005; Teuling et al., 2010). Although some of these processes are already well resolved within land surface models used by climate models, a better description of different rooting systems within the dry deposition schemes might have significant implications for stomatal regulation and thus atmospheric chemistry. We also believe that it will be challenging in the near future to use coupled land surface-chemistry models (e.g. Anav et al., 2012), which allow accounting for the different feedbacks between land surfaces and atmospheric chemistry and physics, especially in a changing climate.

Code availability. The model used in this study is freely available and provided under the GNU general public license. The source code along with the corresponding technical documentation can be obtained from the CHIMERE web site at http://www.lmd. polytechnique.fr/chimere/. All measurement data are publicly available.

Competing interests. The authors declare that they have no conflict of interest.

Acknowledgements. We thank the investigators and the teams managing the eddy-flux sites. We also acknowledge the entire EMEP and AIRBASE staff for providing ground-based $\mathrm{O}_{3}$ data and the EMEP/MSC-W team for the anthropogenic emissions database. The computing resources and the related technical support used for this work were provided by CRESCO/ENEAGRID High Performance Computing infrastructure and its staff (http://www.cresco.enea.it, last access: 20 April 2018). CRESCO/ENEAGRID High Performance Computing infrastructure is funded by ENEA, by the Italian National Agency for New Technologies, Energy and Sustainable Economic Development, and by national and European research programmes. Financial support was from the MITIMPACT project (INTERREG V-A France-Italy ALCOTRA). This work was carried out within the IUFRO Task Force on Climate Change and Forest Health.

Edited by: Leiming Zhang

Reviewed by: two anonymous referees

\section{References}

Ainsworth, E. A., Yendrek, C. R., Sitch, S., Collins, W. J., and Emberson, L. D.: The effects of tropospheric ozone on net pri- 
mary productivity and implications for climate change, Annu. Rev. Plant Biol., 63, 637-661, https://doi.org/10.1146/annurevarplant-042110-103829, 2012.

Allen, R. G., Pereira, L. S., Raes, D., and Smith, M.: Crop evapotranspiration - guidelines for computing crop water requirements, FAO Irrigation and Drainage Paper 56, FAO - Food and Agriculture Organization of the United Nations, Rome, http: //www.fao.org/docrep/X0490E/X0490E00.htm (last access: 20 April 2018), 1998.

Al-Shrafany, D., Rico-Ramirez, M. A., Han, D., and Bray, M.: Comparative assessment of soil moisture estimation from land surface model and satellite remote sensing based on catchment water balance, Meteorol. Appl., 21, 521-534, https://doi.org/10.1002/met.1357, 2014.

Anav, A., Menut, L., Khvorostyanov, D., and Viovy, N.: A comparison of two canopy conductance parameterizations to quantify the interactions between surface ozone and vegetation over Europe, J. Geophys. Res.-Biogeo., 117, G03027, https://doi.org/10.1029/2012jg001976, 2012.

Anav, A., De Marco, A., Proietti, C., Alessandri, A., Dell'Aquila, A., Cionni, I., Friedlingstein, P., Khvorostyanov, D., Menut, L., Paoletti, E., Sicard, P., Sitch, S., and Vitale, M.: Comparing concentration-based (AOT40) and stomatal uptake (PODY) metrics for ozone risk assessment to European forests, Glob. Change Biol., 22, 1608-1627, https://doi.org/10.1111/gcb.13138, 2016.

Anav, A., Liu, Q., De Marco, A., Proietti, C., Savi, F., Paoletti, E., and Piao, S.: The role of plant phenology in stomatal ozone flux modeling, Glob. Change Biol., 24, 235-248, https://doi.org/10.1111/gcb.13823, 2017.

Aranda, I., Forner, A., Cuesta, B., and Valladares, F.: Speciesspecific water use by forest tree species: from the tree to the stand, Agr. Water Manage., 114, 67-77, 2012.

Bolte, A., Czajkowski, T., and Kompa, T.: The north-eastern distribution range of European beech a review, Forestry, 80, 413-429, https://doi.org/10.1093/forestry/cpm028, 2007.

Boynard, A., Hurtmans, D., Koukouli, M. E., Goutail, F., Bureau, J., Safieddine, S., Lerot, C., Hadji-Lazaro, J., Wespes, C., Pommereau, J.-P., Pazmino, A., Zyrichidou, I., Balis, D., Barbe, A., Mikhailenko, S. N., Loyola, D., Valks, P., Van Roozendael, M., Coheur, P.-F., and Clerbaux, C.: Seven years of IASI ozone retrievals from FORLI: validation with independent total column and vertical profile measurements, Atmos. Meas. Tech., 9, 43274353, https://doi.org/10.5194/amt-9-4327-2016, 2016.

Büker, P., Morrissey, T., Briolat, A., Falk, R., Simpson, D., Tuovinen, J. P., Alonso, R., Barth, S., Baumgarten, M., Grulke, N., Karlsson, P. E., King, J., Lagergren, F., Matyssek, R., Nunn, A., Ogaya, R., Peñuelas, J., Rhea, L., Schaub, M., Uddling, J., Werner, W., and Emberson, L. D.: $\mathrm{DO}_{3} \mathrm{SE}$ modelling of soil moisture to determine ozone flux to forest trees, Atmos. Chem. Phys., 12, 5537-5562, https://doi.org/10.5194/acp-125537-2012, 2012.

Canadell, J., Jackson, R., Ehleringer, J., Mooney, H., Sala, O., and Schulze, E.-D.: Maximum rooting depth of vegetation types at the global scale, Oecologia, 108, 583-595, 1996.

Chen, F. and Dudhia, J.: Coupling an advanced land surfacehydrology model with the Penn State-NCAR MM5 modeling system, Part I: Model implementation and sensitivity, Mon. Weather Rev., 129, 569-585, 2001.
CHIMERE: A multi-scale chemistry-transport model for atmospheric composition analysis and forecast, available at: http: //www.lmd.polytechnique.fr/chimere/, 2018.

Ciais, P., Reichstein, M., Viovy, N., Granier, A., Ogee, J., Allard, V., Aubinet, M., Buchmann, N., Bernhofer, C., Carrara, A., Chevallier, F., De Noblet, N., Friend, A. D., Friedlingstein, P., Grunwald, T., Heinesch, B., Keronen, P., Knohl, A., Krinner, G., Loustau, D., Manca, G., Matteucci, G., Miglietta, F., Ourcival, J. M., Papale, D., Pilegaard, K., Rambal, S., Seufert, G., Soussana, J. F., Sanz, M. J., Schulze, E. D., Vesala, T., and Valentini, R.: Europe-wide reduction in primary productivity caused by the heat and drought in 2003, Nature, 437, 529-533, https://doi.org/10.1038/nature03972, 2005.

Cieslik, S., Omasa, K., and Paoletti, E.: Why and how terrestrial plants exchange gases with air, Plant. Biol., 11, 24-34, https://doi.org/10.1111/j.1438-8677.2009.00262.x, 2009.

Craine, J. M., Ocheltree, T. W., Nippert, J. B., Towne, E. G., Skibbe, A. M., Kembel, S. W., and Fargione, J. E.: Global diversity of drought tolerance and grassland climate-change resilience, Nature Climate Change, 3, 63-67, https://doi.org/10.1038/nclimate1634, 2013.

De Marco, A., Sicard, P., Fares, S., Tuovinen, J.-P., Anav, A., and Paoletti, E.: Assessing the role of soil water limitation in determining the Phytotoxic Ozone Dose (PODY) thresholds, Atmos. Environ., 147, 88-97, https://doi.org/10.1016/j.atmosenv.2016.09.066, 2016.

Dee, D. P., Uppala, S. M., Simmons, A. J., Berrisford, P., Poli, P., Kobayashi, S., Andrae, U., Balmaseda, M. A., Balsamo, G., Bauer, P., Bechtold, P., Beljaars, A. C. M., van de Berg, L., Bidlot, J., Bormann, N., Delsol, C., Dragani, R., Fuentes, M., Geer, A. J., Haimberger, L., Healy, S. B., Hersbach, H., Hólm, E. V., Isaksen, L., Kållberg, P., Köhler, M., Matricardi, M., McNally, A. P., Monge-Sanz, B. M., Morcrette, J. J., Park, B. K., Peubey, C., de Rosnay, P., Tavolato, C., Thépaut, J. N., and Vitart, F.: The ERA-Interim reanalysis: configuration and performance of the data assimilation system, Q. J. Roy. Meteor. Soc., 137, 553-597, https://doi.org/10.1002/qj.828, 2011.

Domec, J. C., King, J. S., Noormets, A., Treasure, E., Gavazzi, M. J., Sun, G., and McNulty, S. G.: Hydraulic redistribution of soil water by roots affects whole-stand evapotranspiration and net ecosystem carbon exchange, New Phytol., 187, 171-183, https://doi.org/10.1111/j.1469-8137.2010.03245.x, 2010.

Dy, C. Y. and Fung, J. C. H.: Updated global soil map for the Weather Research and Forecasting model and soil moisture initialization for the Noah land surface model, J. Geophys. Res.Atmos., 121, 8777-8800, https://doi.org/10.1002/2015jd024558, 2016.

Eamus, D.: How does ecosystem water balance affect net primary productivity of woody ecosystems?, Funct. Plant Biol., 30, 187205, 2003.

Emberson, L., Ashmore, M., Cambridge, H., Simpson, D., and Tuovinen, J.-P.: Modelling stomatal ozone flux across Europe, Environ. Pollut., 109, 403-413, 2000.

Emberson, L. D., Büker, P., and Ashmore, M. R.: Assessing the risk caused by ground level ozone to European forest trees: a case study in pine, beech and oak across different climate regions, Environ. Pollut., 147, 454-466, 2007.

Flechard, C. R., Nemitz, E., Smith, R. I., Fowler, D., Vermeulen, A. T., Bleeker, A., Erisman, J. W., Simpson, D., Zhang, L., Tang, 
Y. S., and Sutton, M. A.: Dry deposition of reactive nitrogen to European ecosystems: a comparison of inferential models across the NitroEurope network, Atmos. Chem. Phys., 11, 2703-2728, https://doi.org/10.5194/acp-11-2703-2011, 2011.

Folberth, G. A., Hauglustaine, D. A., Lathière, J., and Brocheton, F.: Interactive chemistry in the Laboratoire de Météorologie Dynamique general circulation model: model description and impact analysis of biogenic hydrocarbons on tropospheric chemistry, Atmos. Chem. Phys., 6, 2273-2319, https://doi.org/10.5194/acp-6-2273-2006, 2006.

Gielen, B., Löw, M., Deckmyn, G., Metzger, U., Franck, F., Heerdt, C., Matyssek, R., Valcke, R., and Ceulemans, R.: Chronic ozone exposure affects leaf senescence of adult beech trees: a chlorophyll fluorescence approach, J. Exp. Bot., 58, 785-795, 2007.

Ginoux, P., Chin, M., Tegen, I., Prospero, J. M., Holben, B., Dubovik, O., and Lin, S. J.: Sources and distributions of dust aerosols simulated with the GOCART model, J. Geophys. Res.Atmos., 106, 20255-20273, 2001.

Granier, A., Huc, R., and Barigah, S.: Transpiration of natural rain forest and its dependence on climatic factors, Agr. Forest Meteorol., 78, 19-29, 1996.

Granier, A., Reichstein, M., Bréda, N., Janssens, I., Falge, E., Ciais, P., Grünwald, T., Aubinet, M., Berbigier, P., and Bernhofer, C.: Evidence for soil water control on carbon and water dynamics in European forests during the extremely dry year: 2003, Agr. Forest Meteorol., 143, 123-145, 2007.

Greve, P., Warrach-Sagi, K., and Wulfmeyer, V.: Evaluating soil water content in a WRF-Noah downscaling experiment, J. Appl. Meteorol. Climatol., 52, 2312-2327, 2013.

Guehl, J., Aussenac, G., Bouachrine, J., Zimmermann, R., Pennes, J., Ferhi, A., and Grieu, P.: Sensitivity of leaf gas exchange to atmospheric drought, soil drought, and water-use efficiency in some Mediterranean Abies species, Can. J. Forest Res., 21, 1507-1515, 1991.

Guenther, A., Karl, T., Harley, P., Wiedinmyer, C., Palmer, P. I., and Geron, C.: Estimates of global terrestrial isoprene emissions using MEGAN (Model of Emissions of Gases and Aerosols from Nature), Atmos. Chem. Phys., 6, 3181-3210, https://doi.org/10.5194/acp-6-3181-2006, 2006.

Hardacre, C., Wild, O., and Emberson, L.: An evaluation of ozone dry deposition in global scale chemistry climate models, Atmos. Chem. Phys., 15, 6419-6436, https://doi.org/10.5194/acp15-6419-2015, 2015.

Hauglustaine, D., Hourdin, F., Jourdain, L., Filiberti, M. A., Walters, S., Lamarque, J. F., and Holland, E.: Interactive chemistry in the Laboratoire de Météorologie Dynamique general circulation model: Description and background tropospheric chemistry evaluation, J. Geophys. Res.-Atmos., 109, D04314, https://doi.org/10.1029/2003JD003957, 2004.

Hibbard, K., Janetos, A., van Vuuren, D. P., Pongratz, J., Rose, S. K., Betts, R., Herold, M., and Feddema, J. J.: Research priorities in land use and land-cover change for the Earth system and integrated assessment modelling, Int. J. Climatol., 30, 2118-2128, 2010.

Hong, S.-Y., Dudhia, J., and Chen, S.-H.: A revised approach to ice microphysical processes for the bulk parameterization of clouds and precipitation, Mon. Weather Rev., 132, 103-120, 2004.
Hong, S.-Y., Noh, Y., and Dudhia, J.: A new vertical diffusion package with an explicit treatment of entrainment processes, Mon. Weather Rev., 134, 2318-2341, 2006.

Hoshika, Y., Katata, G., Deushi, M., Watanabe, M., Koike, T., and Paoletti, E.: Ozone-induced stomatal sluggishness changes carbon and water balance of temperate deciduous forests, Sci. Rep., 5, srep09871, https://doi.org/10.1038/srep09871, 2015.

Jackson, R., Canadell, J., Ehleringer, J., Mooney, H., Sala, O., and Schulze, E.: A global analysis of root distributions for terrestrial biomes, Oecologia, 108, 389-411, 1996.

Jackson, R. B., Sperry, J. S., and Dawson, T. E.: Root water uptake and transport: using physiological processes in global predictions, Trends in Plant Sci., 5, 482-488, 2000.

Jarvis, P.: The interpretation of the variations in leaf water potential and stomatal conductance found in canopies in the field, Philos. T. Ro. Soc. Lond. B, 273, 593-610, 1976.

Kain, J. S.: The Kain-Fritsch convective parameterization: an update, J. Appl. Meteorol., 43, 170-181, 2004.

Karlsson, P. E., Klingberg, J., Engardt, M., Andersson, C., Langner, J., Karlsson, G. P., and Pleijel, H.: Past, present and future concentrations of ground-level ozone and potential impacts on ecosystems and human health in northern Europe, Sci. Total Environ., 576, 22-35, 2017.

Karnosky, D., Percy, K. E., Xiang, B., Callan, B., Noormets, A., Mankovska, B., Hopkin, A., Sober, J., Jones, W., and Dickson, R.: Interacting elevated $\mathrm{CO}_{2}$ and tropospheric $\mathrm{O}_{3}$ predisposes aspen (Populus tremuloides Michx.) to infection by rust (Melampsora medusae $f$. sp. tremuloidae), Glob. Change Biol., 8, 329338, 2002.

Klingberg, J., Engardt, M., Karlsson, P. E., Langner, J., and Pleijel, H.: Declining ozone exposure of European vegetation under climate change and reduced precursor emissions, Biogeosciences, 11, 5269-5283, https://doi.org/10.5194/bg-11-5269-2014, 2014.

Lattuati, M.: Impact des émissions européennes sur le bilan de l'ozone troposphérique à l'interface de l'Europe et de l'Atlantique nord: apport de la modélisation lagrangienne et des mesures en altitude, Phd thesis, Université P. M. Curie, Paris, France, 1997.

Loveland, T. R., Reed, B. C., Brown, J. F., Ohlen, D. O., Zhu, Z., Yang, L., and Merchant, J. W.: Development of a global land cover characteristics database and IGBP DISCover from $1 \mathrm{~km}$ AVHRR data, Int. J. Remote Sens., 21, 1303-1330, 2000.

Mailler, S., Menut, L., di Sarra, A. G., Becagli, S., Di Iorio, T., Bessagnet, B., Briant, R., Formenti, P., Doussin, J.-F., Gómez-Amo, J. L., Mallet, M., Rea, G., Siour, G., Sferlazzo, D. M., Traversi, R., Udisti, R., and Turquety, S.: On the radiative impact of aerosols on photolysis rates: comparison of simulations and observations in the Lampedusa island during the ChArMEx/ADRIMED campaign, Atmos. Chem. Phys., 16, 1219-1244, https://doi.org/10.5194/acp-16-1219-2016, 2016.

Mailler, S., Menut, L., Khvorostyanov, D., Valari, M., Couvidat, F., Siour, G., Turquety, S., Briant, R., Tuccella, P., Bessagnet, B., Colette, A., Létinois, L., Markakis, K., and Meleux, F.: CHIMERE-2017: from urban to hemispheric chemistrytransport modeling, Geosci. Model Dev., 10, 2397-2423, https://doi.org/10.5194/gmd-10-2397-2017, 2017.

Martínez-Fernández, J., González-Zamora, A., Sánchez, N., and Gumuzzio, A.: A soil water based index as a suitable agricultural drought indicator, J. Hydrol., 522, 265-273, 2015. 
Martínez-Ferri, E., Balaguer, L., Valladares, F., Chico, J., and Manrique, E.: Energy dissipation in drought-avoiding and droughttolerant tree species at midday during the Mediterranean summer, Tree Physiol., 20, 131-138, 2000.

Menut, L., Bessagnet, B., Khvorostyanov, D., Beekmann, M., Blond, N., Colette, A., Coll, I., Curci, G., Foret, G., Hodzic, A., Mailler, S., Meleux, F., Monge, J.-L., Pison, I., Siour, G., Turquety, S., Valari, M., Vautard, R., and Vivanco, M. G.: CHIMERE 2013: a model for regional atmospheric composition modelling, Geosci. Model Dev., 6, 981-1028, https://doi.org/10.5194/gmd-6-981-2013, 2013.

Mészáros, R., Zsély, I. G., Szinyei, D., Vincze, C., and Lagzi, I.: Sensitivity analysis of an ozone deposition model, Atmos. Environ., 43, 663-672, 2009.

Mills, G., Pleijel, H., Braun, S., Büker, P., Bermejo, V., Calvo, E., Danielsson, H., Emberson, L., Fernández, I. G., and Grünhage, L.: New stomatal flux-based critical levels for ozone effects on vegetation, Atmos. Environ., 45, 5064-5068, 2011.

Mlawer, E. J., Taubman, S. J., Brown, P. D., Iacono, M. J., and Clough, S. A.: Radiative transfer for inhomogeneous atmospheres: RRTM, a validated correlated-k model for the longwave, J. Geophys. Res.-Atmos., 102, 16663-16682, 1997.

Monks, P. S., Archibald, A. T., Colette, A., Cooper, O., Coyle, M., Derwent, R., Fowler, D., Granier, C., Law, K. S., Mills, G. E., Stevenson, D. S., Tarasova, O., Thouret, V., von Schneidemesser, E., Sommariva, R., Wild, O., and Williams, M. L.: Tropospheric ozone and its precursors from the urban to the global scale from air quality to short-lived climate forcer, Atmos. Chem. Phys., 15, 8889-8973, https://doi.org/10.5194/acp-15-8889-2015, 2015.

Myhre, G., Shindell, D., Bréon, F.-M., Collins, W., Fuglestvedt, J., Huang, J., Koch, D., Lamarque, J.-F., Lee, D., and Mendoza, B.: Anthropogenic and natural radiative forcing, Climate Change, 423, 658-740, 2013.

Pataki, D. and Oren, R.: Species differences in stomatal control of water loss at the canopy scale in a mature bottomland deciduous forest, Adv. Water Resour., 26, 1267-1278, 2003.

Pataki, D. E., Oren, R., and Smith, W. K.: Sap flux of cooccurring species in a western subalpine forest during seasonal soil drought, Ecology, 81, 2557-2566, 2000.

Picon, C., Guehl, J., and Ferhi, A.: Leaf gas exchange and carbon isotope composition responses to drought in a drought-avoiding (Pinus pinaster) and a drought-tolerant (Quercus petraea) species under present and elevated atmospheric $\mathrm{CO}_{2}$ concentrations, Plant Cell Environ., 19, 182-190, 1996.

Reichstein, M., Ciais, P., Papale, D., Valentini, R., Running, S., Viovy, N., Cramer, W., Granier, A., Ogee, J., and Allard, V.: Reduction of ecosystem productivity and respiration during the $\mathrm{Eu}-$ ropean summer 2003 climate anomaly: a joint flux tower, remote sensing and modelling analysis, Glob. Change Biol., 13, 634651, 2007.

Reynolds, J. F., Smith, D. M. S., Lambin, E. F., Turner, B., Mortimore, M., Batterbury, S. P., Downing, T. E., Dowlatabadi, H., Fernández, R. J., and Herrick, J. E.: Global desertification: building a science for dryland development, Science, 316, 847-851, 2007.

Schaake, J. C., Koren, V. I., Duan, Q. Y., Mitchell, K., and Chen, F.: Simple water balance model for estimating runoff at different spatial and temporal scales, J. Geophys. Res.-Atmos., 101, 7461$7475,1996$.
Schenk, H. J. and Jackson, R. B.: Rooting depths, lateral root spreads and below-ground/above-ground allometries of plants in water-limited ecosystems, J. Ecol., 90, 480-494, 2002.

Schwede, D., Zhang, L., Vet, R., and Lear, G.: An intercomparison of the deposition models used in the CASTNET and CAPMoN networks, Atmos. Environ., 45, 1337-1346, 2011.

Schwinning, S., Starr, B. I., and Ehleringer, J. R.: Summer and winter drought in a cold desert ecosystem (Colorado Plateau) part I: effects on soil water and plant water uptake, J. Arid Environ., 60, 547-566, 2005.

Seinfeld, J. H. and Pandis, S. N.: Atmospheric chemistry and physics: from air pollution to climate change, John Wiley \& Sons, 2016.

Sertel, E., Robock, A., and Ormeci, C.: Impacts of land cover data quality on regional climate simulations, Int. J. Climatol., 30, 1942-1953, 2010.

Shindell, D. T., Faluvegi, G., Koch, D. M., Schmidt, G. A., Unger, N., and Bauer, S. E.: Improved attribution of climate forcing to emissions, Science, 326, 716-718, 2009.

Shindell, D. T., Lamarque, J.-F., Schulz, M., Flanner, M., Jiao, C., Chin, M., Young, P. J., Lee, Y. H., Rotstayn, L., Mahowald, N., Milly, G., Faluvegi, G., Balkanski, Y., Collins, W. J., Conley, A. J., Dalsoren, S., Easter, R., Ghan, S., Horowitz, L., Liu, X., Myhre, G., Nagashima, T., Naik, V., Rumbold, S. T., Skeie, R., Sudo, K., Szopa, S., Takemura, T., Voulgarakis, A., Yoon, J.-H., and Lo, F.: Radiative forcing in the ACCMIP historical and future climate simulations, Atmos. Chem. Phys., 13, 2939-2974, https://doi.org/10.5194/acp-13-2939-2013, 2013.

Sicard, P., De Marco, A., Dalstein-Richier, L., Tagliaferro, F., Renou, C., and Paoletti, E.: An epidemiological assessment of stomatal ozone flux-based critical levels for visible ozone injury in Southern European forests, Sci. Total Environ., 541, 729-741, 2016.

Simpson, D., Ashmore, M. R., Emberson, L., and Tuovinen, J.-P.: A comparison of two different approaches for mapping potential ozone damage to vegetation. A model study, Environ. Pollut., 146, 715-725, 2007.

Simpson, D., Benedictow, A., Berge, H., Bergström, R., Emberson, L. D., Fagerli, H., Flechard, C. R., Hayman, G. D., Gauss, M., Jonson, J. E., Jenkin, M. E., Nyíri, A., Richter, C., Semeena, V. S., Tsyro, S., Tuovinen, J.-P., Valdebenito, Á., and Wind, P.: The EMEP MSC-W chemical transport model - technical description, Atmos. Chem. Phys., 12, 7825-7865, https://doi.org/10.5194/acp-12-7825-2012, 2012.

Sitch, S., Cox, P., Collins, W., and Huntingford, C.: Indirect radiative forcing of climate change through ozone effects on the landcarbon sink, Nature, 448, 791-794, 2007.

Skamarock, W. C. and Klemp, J. B.: A time-split nonhydrostatic atmospheric model for weather research and forecasting applications, J. Comput. Phys., 227, 3465-3485, 2008.

Solazzo, E., Hogrefe, C., Colette, A., Garcia-Vivanco, M., and Galmarini, S.: Advanced error diagnostics of the CMAQ and Chimere modelling systems within the AQMEII3 model evaluation framework, Atmos. Chem. Phys., 17, 10435-10465, https://doi.org/10.5194/acp-17-10435-2017, 2017.

Terrenoire, E., Bessagnet, B., Rouïl, L., Tognet, F., Pirovano, G., Létinois, L., Beauchamp, M., Colette, A., Thunis, P., Amann, M., and Menut, L.: High-resolution air quality simulation over Europe with the chemistry transport model CHIMERE, Geosci. 
Model Dev., 8, 21-42, https://doi.org/10.5194/gmd-8-21-2015, 2015.

Teuling, A. J., Seneviratne, S. I., Stöckli, R., Reichstein, M., Moors, E., Ciais, P., Luyssaert, S., Van Den Hurk, B., Ammann, C., and Bernhofer, C.: Contrasting response of European forest and grassland energy exchange to heatwaves, Nat. Geosci., 3, 722727,2010

Tuovinen, J.-P., Ashmore, M., Emberson, L., and Simpson, D.: Testing and improving the EMEP ozone deposition module, Atmos. Environ., 38, 2373-2385, 2004.

Tuovinen, J.-P., Emberson, L., and Simpson, D.: Modelling ozone fluxes to forests for risk assessment: status and prospects, Ann. For. Sci., 66, 1-14, 2009.

Vestreng, V., Ntziachristos, L., Semb, A., Reis, S., Isaksen, I. S. A., and Tarrasón, L.: Evolution of $\mathrm{NO}_{x}$ emissions in Europe with focus on road transport control measures, Atmos. Chem. Phys., 9, 1503-1520, https://doi.org/10.5194/acp-9-1503-2009, 2009.

Wesely, M.: Parameterization of surface resistances to gaseous dry deposition in regional-scale numerical models, Atmos. Environ., 23, 1293-1304, 1989.

Vinceti, B., Paoletti, E., and Wolf, U.: Analysis of soil, roots and mycorrhizae in a Norway spruce declining forest, Chemosphere, 36, 937-942, 1998.
Wild, O., Zhu, X., and Prather, M. J.: Fast-J: Accurate simulation of in-and below-cloud photolysis in tropospheric chemical models, J. Atmos. Chem., 37, 245-282, 2000.

Wittig, V. E., Ainsworth, E. A., Naidu, S. L., Karnosky, D. F., and Long, S. P.: Quantifying the impact of current and future tropospheric ozone on tree biomass, growth, physiology and biochemistry: a quantitative meta-analysis, Glob. Change Biol., 15, 396-424, 2009.

Wu, X., Liu, H., Li, X., Ciais, P., Babst, F., Guo, W., Zhang, C., Magliulo, V., Pavelka, M., and Liu, S.: Differentiating drought legacy effects on vegetation growth over the temperate Northern Hemisphere, Glob. Change Biol., 24, 504-516, 2017.

Zhu, Z., Bi, J., Pan, Y., Ganguly, S., Anav, A., Xu, L., Samanta, A., Piao, S., Nemani, R. R., and Myneni, R. B.: Global data sets of vegetation leaf area index (LAI) $3 \mathrm{~g}$ and Fraction of Photosynthetically Active Radiation (FPAR) $3 \mathrm{~g}$ derived from Global Inventory Modeling and Mapping Studies (GIMMS) Normalized Difference Vegetation Index (NDVI3g) for the period 1981 to 2011, Remote Sens., 5, 927-948, 2013.

Zhu, Z., Piao, S., Myneni, R. B., Huang, M., Zeng, Z., Canadell, J. G., Ciais, P., Sitch, S., Friedlingstein, P., and Arneth, A.: Greening of the Earth and its drivers, Nature Climate Change, 6, 791795, 2016. 